\title{
Sovietizing Czechoslovak Music: The "Hatchet-Man" Miroslav Barvík and his Speech The Composers Go with the People
}

\author{
THOMAS D. SVATOS
}

Miroslav Barvík (1919-1998) was the most powerful musician in Czechoslovakia during the Czechoslovak Stalinist years. ${ }^{1}$ Barvík's control over Czech musical culture stemmed from his appointment to the Action Committees of the National Front, which were established in February 1948 during the communist seizure of power. The mandate of the Action Committees was to purge all resistance from civic and governmental institutions and ensure complete loyalty to the Party from the ground up. ${ }^{2}$

This study examines Barvík as a young, idealistic, and zealous apparatchik-the strongman of musical politics during the formative phase of the communist regime. I focus on the moment that virtually consecrated his authority over Czechoslovak musical life: his speech to the Union of Czechoslovak Composers (henceforth UCC) for the UCC's first plenary conference in April 1950. Entitled The Composers Go with the People according to the working motto of the conference, Barvík's speech came at a time Cold War tactics abroad and repressive measures at home were escalating to new extremes. ${ }^{3}$ Marking the complete Sovietization of Czech musical culture, the document he produced stands as a landmark in Czech music history, and overall, one of the most fanatically driven musical manifestos ever written.

Had it not been for his role as chief executioner of communist musical policy, Barvík would not merit a study of this size. He is unknown internationally, and even in today's Czech Republic, he is an obscure figure for the reasons I discuss. But the very phenomenon of Barvík is just as important to note, as the role he played as a young apparatchik sheds light on the state of Czech music at this time. The pronouncements of Stalin's cultural commissar Andrei Zhdanov to the various Soviet artistic unions after World War II-including his January 1948 "inquiry" into Soviet music_called for a complete rejection of "anti-people modernism." ${ }^{4}$ On the Czechoslovak music scene, enforcing Zhdanov's doctrines meant settling scores with the country's pre-war modernists, leaving the new positions of authority open to

\footnotetext{
For granting me enlightening interviews on the subject of early communist-era Czech musical culture, I would like to thank Ivan Medek and Ivan Vojtěch. All translations are by the author; rights for all audio-visual materials have been secured where needed. The following abbreviations are used in this study: CCP = Czechoslovak Communist Party; HAMU = Music Faculty of the Academy of Performing Arts; ISCM = International Society for Contemporary Music; SCC = Syndicate of Czechoslovak Composers; UCC $=$ Union of Czechoslovak Composers.

${ }^{1}$ In this study, the period of Czechoslovak Stalinism shall refer to the years 1948-53.

${ }^{2}$ For a discussion of the Action Committees in early communist-era cultural politics, see Jiří Knapík, V zajetí moci. Kulturní politika, jeji systém a aktéri 1948-1956 [In the Captivity of Power: Cultural Politics, its System, and Participants 1948-1956] (Prague: Nakladatelství Libri, 2006), 19 ff.

${ }^{3}$ Miroslav Barvík, Skladatelé jdou s lidem. Referát generálního tajemníka Svazu čs. skladatelů na I. plenárním zasedání SČS v dubnu 1950 [The Composers Go with the People: A Paper Read by the Secretary-General of the Union of Czechoslovak Composers at the First Plenary Meeting of the UCC in April 1950] (Prague: Orbis, 1951).

${ }^{4}$ For more on Zhdanov and his meetings with the Union of Soviet Composers, where the "big four" of Soviet music were censured, i.e. Shostakovich, Prokofiev, Khachaturian, and Myaskovsky, see Alexander Werth, Musical Uproar in Moscow (Westport, Conn.: Greenwood Press, 1973).
} 
young musicians and scholars who had little experience before the Nazi occupation. ${ }^{5}$ This accounts for the strange scenario where a mediocre, thirty-year-old composer dictated musical norms to a country. It also allowed him to censure, for example, the pre-war works of Alois Hába, one of the most influential members of the International Society for Contemporary Music (henceforth ISCM) and the most eminent member of the UCC.

Miroslav Barvík was born in the small south-east Moravian town of Lužice u Hodonína. He studied composition at the Brno Conservatory (1937-42) under the pianist-composer Václav Kaprál, a "socially conscious" musician whose views on the role of music and music education in society left a strong imprint on Barvík as a young man. ${ }^{6}$ Barvík was among Kaprál's most devoted students, and the hardship and tragedies of Kaprál's later life-in addition to Kaprál's death just one year before the "victory" of Czechoslovak communism—drove Barvík's desire to implement socialist ideology in music. ${ }^{7}$

After compositional studies with Vítězslav Novák in Prague (1942-44) and Jaroslav Řídký (following the city's liberation), Barvík returned to Brno to become the director of the conservatory, a position that allowed him to demonstrate his exceptional administrative abilities. Just after the February 1948 coup, the twenty-eight-year-old Barvík descended on Prague as deus ex machina. He became the jednatel, or managing director of the Action Committee that had been established within the ranks of the Syndicate of Czechoslovak Composers (henceforth SCC), one of the most important post-war music organizations. His authority, however, extended well beyond the SCC, as he also served as Secretary to the Music Division of the Central Action Committee; the Central Action Committee was the Party's all-powerful organ that decided who was politically reliable throughout the professional world, all the way up to the parliamentary National Front assembly. ${ }^{8}$ A number of prominent musicians immediately lost their positions at this time and there can be little doubt that Barvík was directly involved. ${ }^{9}$

\footnotetext{
${ }^{5}$ Prepared for the need to school Czech functionaries in Soviet cultural policy, Czech-language translations of Zhdanov's lectures to the various Soviet artistic unions about literature, music, and philosophy were issued as Andrej A. Ždanov, O umění [About Art] (Prague: Orbis, 1949). For more on Zhdanov's policies in Czechoslovak communist culture, see Knapík, Vzajetí, 34 ff.

${ }^{6}$ By qualifying the term "socially conscious," I do not wish to express skepticism over Kaprál's views, but draw attention to the way the communist musicologists attempted to disenfranchise other musicians not seen in this way. In other words, the decisions a musician made as a composer, critic, pedagogue, or performing artist (i.e. choice of repertoire) defined his position in the larger socialist movement as a positive or negative force. Many of Kaprál's numerous essays demonstrating his moderate socialist views were published in the leftist daily newspaper Rovnost [Equality] during the interwar era. For more on Kaprál, see Ludvík Kundera, Václav Kaprál. Kapitola z historie české meziválečné hudby [Václav Kaprál: A Chapter from the History of Czech Interwar Music] (Brno: Nakladatelství Blok, 1968).

${ }^{7}$ The tragedies of Kaprál's later life include the death in June 1940 of his daughter Vítězslava, a composer of exceptional promise who studied with Bohuslav Martinů in Paris but succumbed to tuberculosis during the German invasion; Kaprál's internment to the Nazis for almost three years due to his younger brother Bohumil's service as an officer in the Czechoslovak army in France; and Kaprál's death due to cancer on 6 April 1947. See Kundera, Václav Kaprál. In Kundera's monograph, see in particular pp. 41-43, where Barvík's 1946 essay on Kaprál from Rovnost is reprinted; Barvík's portrait reveals the utmost devotion he and his fellow students had for their teacher and how Barvík regularly visited Kaprál during the latter's incarceration.

${ }^{8}$ For a full enumeration of Barvík's official functions, see Jiř́i Knapík, "Barvík, Miroslav." Kdo byl kdo v naši kulturní politice 19481953 [Who was Who in Our Cultural Politics 1948-1953] (Prague: Nakladatelství Libri, 2002), 48-49.

${ }^{9}$ At one point in my Czech-language interview with Ivan Vojtěch, we discussed the circumstances surrounding the dismissal of the esteemed music critic Gracian Černušák from the Brno Conservatory during the first wave of purges in February-March 1948. Vojtěch recalled how Václav Dobiáš, an SCC Action Committee member, had later defended himself for having signed off on the decision, claiming that Barvík forced him to do it. Vojtěch exclaimed, "Mein Gott, it doesn't make a difference, both of them were involved." See Thomas D. Svatos, Interview with Ivan Vojtěch (Prague, Summer, 2006). For more on Černušák, the repression of musicians, and the culpability of functionaries from 1948 forward, see "Zpráva o činnosti rehabilitační a rekapitulační komise sekce hudebních vědců a kritiků Svazu čs. skladatelů" ["Report on the Activities of the Rehabilitation and Recapitulatory Commission of the Section of Musicologists and Music Critics of the Union of Czechoslovak Composers"] Hudební věda 6, no. 2 (1969): 336-337. The report was issued a number of months before censorship returned in the aftermath of the Soviet invasion.

Ivan Vojtěch (b. 1928), music critic and twentieth-century music scholar, was the functionary of the UCC who led the most vigorous polemics against the Zhdanovites during the 1950s. During his student years, however, he was close to the powerful Zhdanovite music scholar Antonín Sychra, the Dean at HAMU, and he has never been forgiven by some for his severe critique of
} 


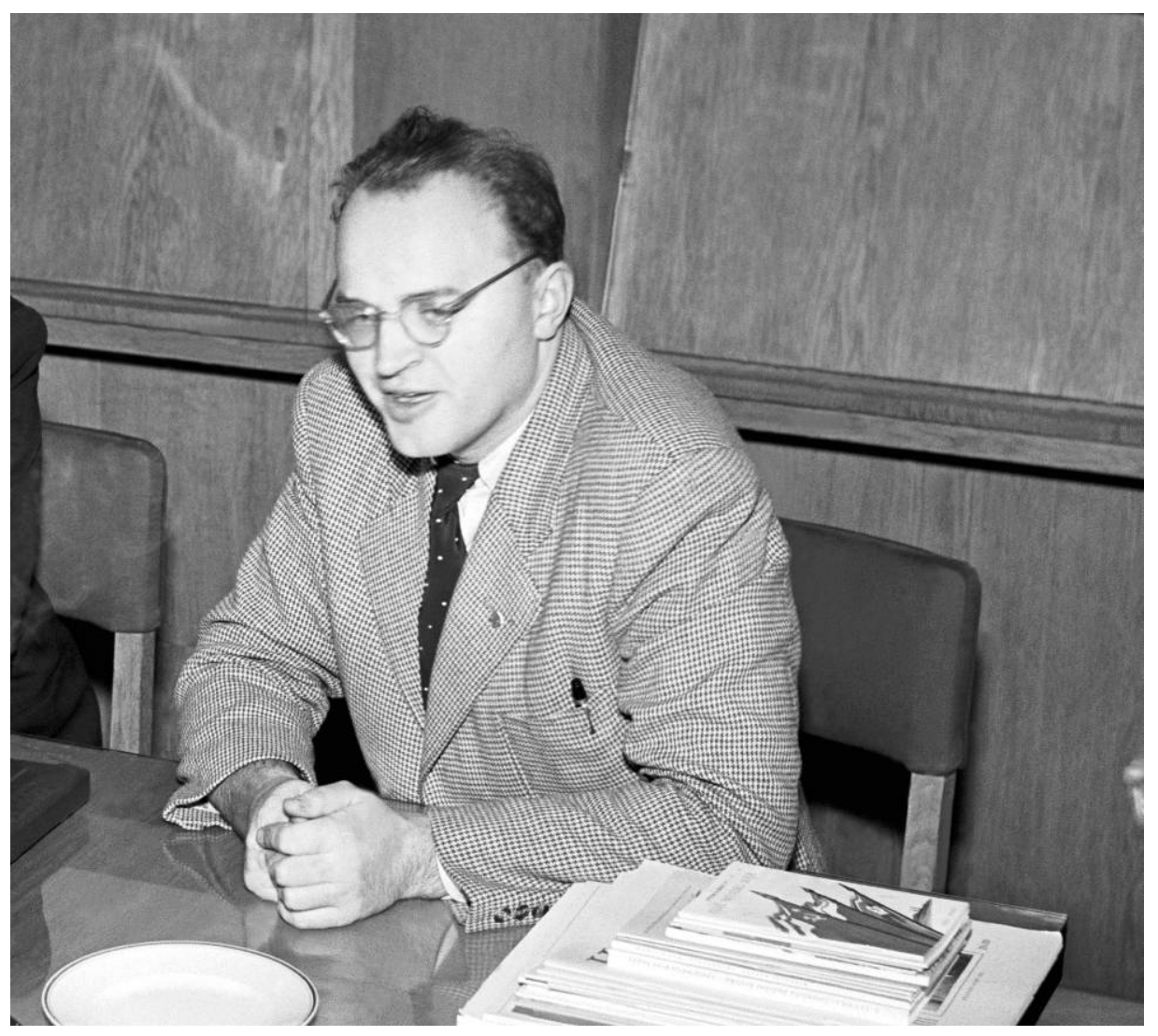

Figure 1. Miroslav Barvík, 14 November 1951.

\section{The Syndicate and the Coup}

In the early days of the coup, Barvík was at the ground floor of the Party's efforts to transform all existing artistic organizations into single, centralized unions, which—on matters of Party policy-were to function as "levers of transmission" process in musical life, before it dissolved into the UCC. Barvík's behind-the-scenes work with the Central Action Committee soon made him feared by musicians throughout the country. ${ }^{11}$ But the positions through which he introduced policy and attempted to persuade the musical community took form as Editor-in-Chief of the official music journal Hudebni rozhledy [Musical Perspectives] and as Secretary-General of the UCC.

Bohuslav Martinů in 1958, seen to uphold the Party line against the disenfranchised émigré composer. See Ivan Vojtěch, "Martinů a soudobá česká hudba" ["Martinů and Contemporary Czech Music"] Literární noviny 7, no. 25 (21 Jun. 1958): 5.

${ }^{10}$ For more on this concept, see Jiří Knapík, Únor a kultura. Sovétizace české kultury 1948-1950 [February and Culture: the Sovietization of Czech Culture 1948-1950] (Prague: Nakladatelství Libri, 2004), 137 ff.

${ }^{11}$ See Viktor Pantůček, "Musica politica. Budování nového řádu” [“Musica Politica: Building the New Order”] Opus musicum 39, no. 1 (2007): 36-37. Pantůček presents two memoranda that Barvík expedited in the name of the Central Action Committee's Music Division to the Club of Moravian Composers in Brno. The first, dated 26 March 1948, draws attention to the Music Division's "wonder" that the Club of Moravian Composers had not yet established its Action Committee, which would pledge allegiance to the communist government of Klement Gottwald; that it had not yet conducted purges within its ranks; and that it had not yet announced its Action Plan for the immediate future. The second, dated 9 April 1948, now addressed to the newly installed Action Committee of the Club of Moravian Composers, "recognizes the Club's position" to immediately fuse with the SCC. At this time, it was believed that the SCC would be the single, centralized music organization in Czechoslovakia. It was later decided that the name "syndicate" had the resonance of the "capitalist" First Republic and that the term "union," in use in the U.S.S.R., was to be preferred. 
Briefly examining the SCC and the coup will help us understand the forces that allowed Barvík to emerge with so much administrative and ideological control. From its inception in February 1946, the SCC was primarily a promotional organization that provided support to composers, managed international relations, and organized events, most notably the Prague Spring International Music Festival, an annual event that began in May 1946. As part of the 1947 festival, the SCC organized the First International Congress of Composers and Music Critics, which ran parallel with the concerts. ${ }^{12}$ In light of its success in reestablishing links between musicians after the war and promoting international debate, the SCC organized a second congress for the following year, which was to address the question, "Where is music heading?" What had prompted this theme was the perceived crisis in music: that the production and performance of serious art music had become too esoteric and was rapidly losing ground to popular, "uncultured" forms. ${ }^{13}$

Intervening between the two congresses were the dramatic political events of late February 1948, when twelve non-communist ministers resigned in protest over what they saw as the Communist Interior Minister's imperious actions. ${ }^{14}$ Rather than face civil war brought on by the "People's Militias," or the communist paramilitary, the president Edvard Beneš sanctioned the appointment of communists to the vacated ministries. On 10 March 1948, the new government was endorsed by the recently purged National Front, or the parliamentary coalition of five political parties that had agreed to a common program of collectivization after the war but was comprised now of only the communists and a number of satellite parties. ${ }^{15}$ It was also on 10 March 1948 that the only remaining non-communist minister, Jan Masaryk, died under mysterious circumstances. ${ }^{16}$

On 30 May 1948, just after the SCC's Second International Congress adjourned, the first mock parliamentary elections were held, where the voters, closely monitored by Party officials, were given the chance to approve the purified National Front, or cast blank "white ballots," a tactic resulting in an $89 \%$ mandate for the assembly. On 7 June 1948, President Beneš resigned and the National Front approved the prime minister and Communist Party leader Klement Gottwald as his successor. Benešs abdication left all organs of power in the hands of the communists, which allowed them to "intensify the class struggle." The full force of this campaign was launched in Fall 1948 with the preparation of the first labor camps and show trials, inducing fear over the entire population.

It was in this stream of events that the SCC's Second International Congress was held, which now called for an outcome that would conform to Soviet socialist realism, the new state's official aesthetic. The congress's resulting document was the "Proclamation and Resolution of the Second International

\footnotetext{
${ }^{12}$ Papers from the congress were published in Hudba národi̊. Sborník přednášek proslovených na I. mezinárodním sjezdu skladateli a hudebnich kritiku v Praze ve dnech 16.-26. V. 1947 [Music of the Nations: Proceedings of the First International Conference of Composers and Music Critics in Prague during the Days 16-26 May 1947] (Prague: Syndikát českých skladatelů, 1948). The participants came from 16 different countries, many from outside the Soviet block.

${ }^{13}$ See Hudba národi̊, 3-4.

${ }^{14}$ The Interior Ministry's purging of Czechoslovak security forces, where communists were installed in place of non-communists, was the main point of protest. See Ivo Duchacek, "The February Coup in Czechoslovakia" World Politics 2, no. 4 (Jul., 1950 ): $521 \mathrm{ff}$.

${ }^{15} \mathrm{By}$ this time, the communists had realized their post-war scheme to infiltrate the opposition with communist fellow-travelers, who then came to the helm of their respective parties by appointment of the Central Action Committee. See Ivo Duchacek, "The Strategy of Communist Infiltration: Czechoslovakia, 1944-48" World Politics 2, no. 3. (Apr., 1950): 345-372.

${ }^{16}$ Jan Masaryk (1886-1948), son of the first Czechoslovak president Tomáš Masaryk, was serving as Minister of Foreign Affairs (without party affiliation) at the time he fell to his death from a window at the Czernín Palace in Prague. His open resistance in Moscow (June 1947) to Stalin's demands for Czechoslovakia to join the Marshall Plan has been seen as grounds for his liquidation, either by Soviet or Czechoslovak communist agents.
} 
Congress of Composers and Music Critics," otherwise known as the "Prague Manifesto." ${ }^{77}$ The Proclamation and Resolution ascribes the crisis in music to capitalist society and calls on composers to abandon "subjectivity" in favor of genres communicating concrete ideas and styles more easily understandable to the masses. ${ }^{18}$ Although the document is clearly consistent with Zhdanov's ideas, it is not yet prescriptive about the particular content the new music should have. That an "open-ended" socialist charter could still be ratified at this time was made possible by the fact that the conference took place one month before the Soviet Union had issued its criticisms of Yugoslavia, quickly putting to an end in Czechoslovakia any ideas about a "specific path" towards socialism. ${ }^{19}$

In October 1948, the organ was established that would provide guidance to composers about the aims of the new music. This was Hudebni rozhledy, ${ }^{20}$ where Barvík served as Editor-in-Chief until 1953. Barvík's mission statement for the new journal makes clear that musical life would be synchronized with the demands of Soviet policy and no other views would be tolerated. ${ }^{21}$ On the discontinuation of all other music periodicals, Barvík writes euphemistically that "there is no more time" for other journals such as Tempo and Rytmus but "we do not mean in any way to belittle their merits in the promotion of our music." 22 He also states that, "in this journal we want for us, composers and musicologists, to learn how to think anew, feel anew, to live anew. We want to help in the search for the new forms of the new life and art. On these pages, we want to help bring into the world the new music that will be a reflection of life in socialist society." ${ }^{23}$

In his mission statement, Barvík also heralds the Gleichschaltung of all professional music organizations, which would bring him to the top of the musical hierarchy. Reflecting his urgency and

\footnotetext{
${ }^{17}$ The English music critic Alan Bush reports on the conference in "The Second International Congress of Composers and Music Critics" The Musical Times (Sep., 1948): 280-81. For an English-language translation of the proclamation, see Nicolas Slonimsky, Music Since 1900, 5th ed. (New York: Schirmer Books, 1994), 1055-57. The Czech-language version was first printed as "Provolání" ["Proclamation"] Hudební rozhledy 1, no. 1 (15. Oct. 1948): 40-41; it was famously critized by Theodor Adorno in his essay "Gegängelte Musik," reprinted in Gesammelte Schriften, vol. 14 (Frankfurt am Main: Suhrkamp Verlag, 1973), 51-66. In Czech, Adorno's essay was published for the first time alongside the 1948 Proclamation as "Hudba na provázku" ["Music on a Leash"] Hudebni věda 6, no. 1(1969): 92-101.

The full proceedings of the SCC's Second International Congress in Prague were never published. Ivan Vojtěch, in attendance as a student, recalls that the individual papers had been made available to the auditors and that he had collected them all for study. He claims that, despite its clearly leftist agenda, the congress maintained a liberal character by tolerating the scheduled program of subjects, some of which would have been unthinkable in Prague two years later. See Svatos, Interview with Ivan Vojtěch. I have yet to examine the papers, but we can propose, that - similar to the way the Darmstadt New Music Festival has been remembered mostly for its marginal, avant-garde serialist wing-Prague's Second International Congress has been remembered for its complete submission to Zhdanov's ideas. See Gianmario Borio and Hermann Danuser, eds., Im Zenit der Moderne. Die Internationalen Ferienkurse für Neue Musik Darmstadt 1946-66, 4 vols. (Freiburg im Br.: Rombach, 1997).

${ }^{18}$ It has been something of a mystery in Czech musicological circles as to who exactly conceived the manifesto. Nevertheless, Alan Bush, in a paper published in 1964, states with no uncertainty that the document was drafted by Hanns Eisler; both Bush and Eisler were participants at the 1948 congress. Bush writes, "It will not be generally known that the draft of the statement which was accepted with only minor changes by congress was largely [Eisler's] work." See Sinn und Form, Sonderheft Hanns Eisler 1964, Berlin, p. 332. For more on the Prague Manifesto, see Miloš Jůzl, "Music and the Totalitarian Regime in Czechoslovakia" International Review of the Aesthetics and Sociology of Music 27, no. 1. (Jun., 1996): 36-38; Miroslav Černý, "Ke kritikám 'Pražského manifestu' od Adorna ke sborníku Musik und Politik" ["From the Criticisms by Adorno of the 'Prague Manifesto' to the Essay Collection Musik und Politik"] Hudební véda 10, nos. 3 \& 4 (1973): 234-243, 326-338; see in particular pg. 237, fn. 12. Also see Jaromir Havlík, "The Prague Manifesto after (almost) sixty years" (1 Apr. 2007) The Free Library: http://www.thefreelibrary.com.

${ }^{19}$ See Jiří Knapík, Únor a kultura, 89 ff.

${ }^{20}$ The full title of the Czechoslovak analogy to Sovetskaya muzika is Hudebni rozhledy. Měsícník skladatelů a hudebních vědcu Československa [Musical Perspectives: a Monthly Journal for Composers and Musicologists in Czechoslovakia].

${ }^{21}$ See Hudebni rozhledy 1, no. 1 (15 Oct. 1948): 1-2. Barvík’s introductory essay to the new journal bears no title.

${ }^{22}$ Ibid., 1.

${ }^{23} \mathrm{Ibid}$. If it was unclear by now what direction music was taking, musicians and scholars could look to Barvík's cantatas from this time, which included Gratitude to the Soviet Union, Song about the Soviet Land, A Pioneer's Fairy-Tale, and Hands off Korea!, the last of which won him an honorary prize in the brethren socialist nation of North Korea. Barvík composed these works between the years 1947-53.
} 
impatience, he writes, "it only remains for us to finish the process of consolidating societies that unnecessarily squander our efforts and today no longer have 'raison d'être', for in most cases they emerged during the [national] revivalist times or mature capitalism and whose creative artists and patrons came together in conjunction with these concerns." ${ }^{24}$

The final consolidation of musical life was realized in May 1949 with the incorporation of the SCC and several other music associations into the UCC. ${ }^{25}$ Contributing to his growing megalomania, Barvík acquired the authoritarian, Soviet-style title of "Secretary-General," marking his complete administrative control over the national music scene. ${ }^{26}$

The first plenary conference of the UCC was held in April 1950 under the banner The Composers Go with the People, where Barvík gave the principal address. ${ }^{27}$ Ostensibly, the event's rationale was to rally support among composers to make statements in the name of the socialist cause. The ulterior motive, however, was to censure those musicians perceived out of line with Party policy. Miloš Jůzl, in his study "Music in the Totalitarian Regime," describes the ramifications of speeches read by executive functionaries at union meetings:

Every so often introductory speeches at annual meetings of the Union of Czechoslovak Composers might contain critical objections against particular composers, music historians, or musicologists, who would then experience many difficulties. These reports were then consulted with the Secretariat of the Central Committee of the Communist Party, and this also applied to all the other artists' unions. Communist union officials were then required 'to rectify the deficiencies that were found'; so it was left to the moral and professional qualities of union officials as to how strongly these directives would be applied within a particular union. ${ }^{28}$

I shall now turn to the actual content of Barvík's speech, which will show exactly which musicians were favored or disenfranchised. In addition, we shall learn the particular narrative through which Barvík vindicates the development and "victory" of socialist music and how he castigates those forces that had stood in its way. But most of all, we should remember that Barvík read his speech during the most oppressive reign of terror, when virtually any citizen could be suddenly charged with treason against the working class, incarcerated, sentenced to years of "class-conscience reeducation" (i.e. hard labor), and in some cases death. Thus, although we might read his speech today with a sense of amusement over its outlandish formulations, the auditors could not help but be unsettled by the fact that their union executive would then report his opinions, perhaps putting to an end their livelihood and careers. ${ }^{29}$

\footnotetext{
${ }^{24}$ Ibid., 2.

${ }^{25}$ See "II. Sjezd československých skladatelů a hudebních vědců" ["Second Conference of Czechoslovak Composers and Musicologists"] Hudebni rozhledy 1, no. 10 (20. August 1949): 224-226.

${ }^{26}$ In the report on the conference that consecrated the UCC (see ibid.), it is claimed that Barvík was "elected" Secretary-General. Whether or not there was any choice but to elect to this position the Secretary to the Central Action Committee's Music Division-or in what form the election was held-is unclear. Vojtěch remarked that the title of Secretary-General-reminiscent of the Soviet commissars - contributed to Barvík's megalomania. Svatos, Interview with Ivan Vojtèch. With the abolition of the SCC, the work of the SCC's Action Committee also came to an end, leaving control of musical life in the hands of the UCC's Secretary-General and Central Committee.

${ }^{27}$ The proceedings of the UCC's first plenary conference were published as "Skladatelé jdou s lidem. Zpráva o I. pracovním plenárním zasedání Svazu čs. skladatelů ve dnech 22.-25. IV. 1950” [“Composers Go with the People: a Report on the First Working Plenary Session of the Union of Czechoslovak Composers during the days 22-25 April 1950"], Hudebni rozhledy 2, nos. 8-9 (25 June 1950): 198-233. Printed here are only excerpts from Barvík's speech, which lasted three hours and which was interrupted by the entrance into the hall of the elderly Education Minister Zdeněk Nejedlý, who was allowed to give his own speech. Unlike the SCC's 1948 congress, foreign participants came only from Soviet Block countries; the conference was part of a larger event that included concerts demonstrating the newest in Czechoslovak socialist music.

${ }^{28}$ Jůzl, 46.

${ }^{29}$ As a note of explanation before the full text of his speech, Barvík explains, "Lady and gentlemen comrades, valued friends, esteemed and dear guests! The presidium of the Union of Czechoslovak Composers has entrusted me to give a theoretical
} 


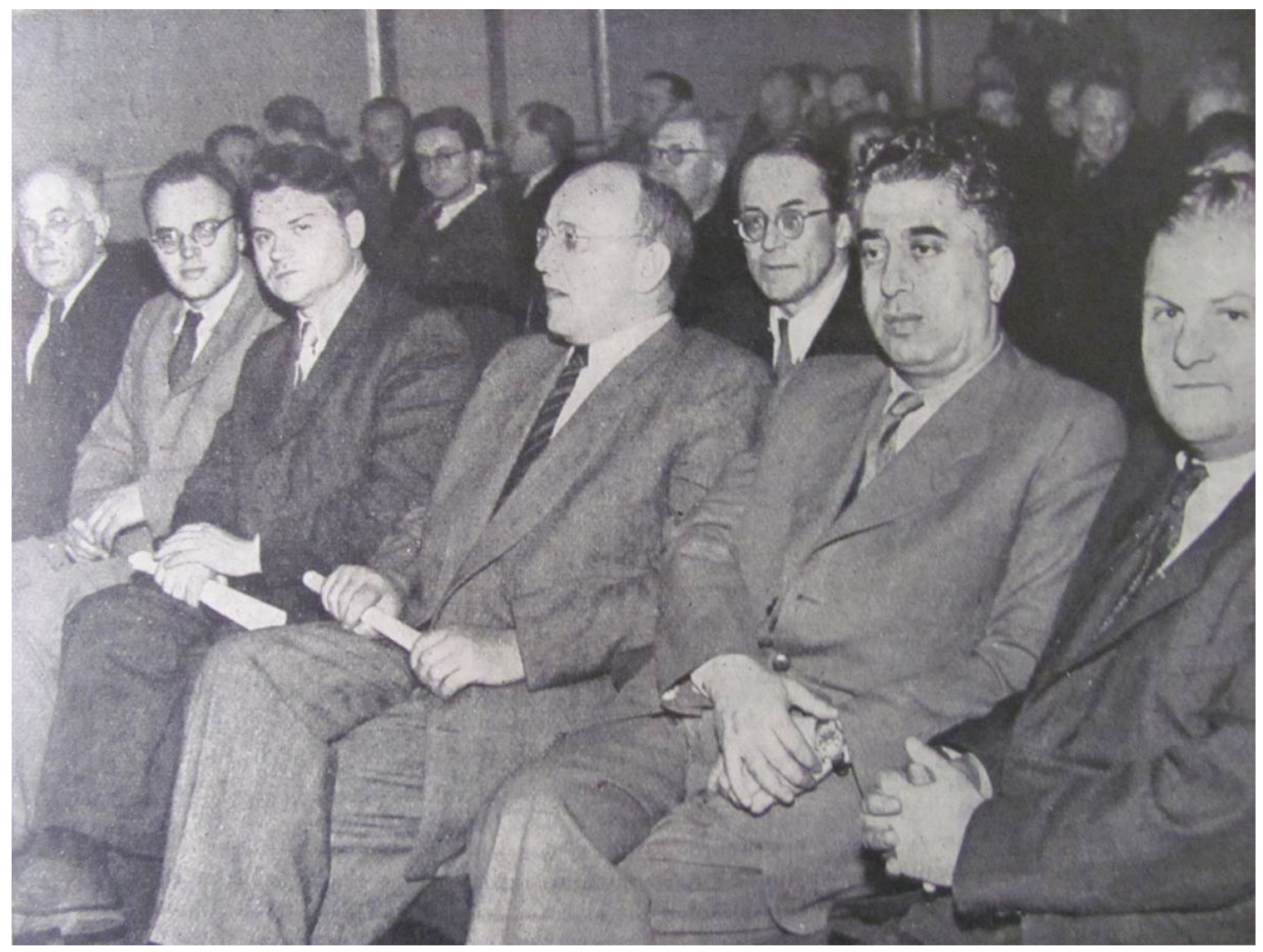

Figure 2. Leading Czechoslovak and Soviet participants at the UCC's first plenary session (from the right): chair of the plenary session Antonín Sychra, Aram Khachaturian, Mikhail Chulaki, GeneralSecretary of the Union of Soviet Composers Tikhon Khrennikov, General-Secretary of the UCC Miroslav Barvík, and Josef Stanislav; in the second row the translator A. Waulin.

presentation about the situation on the musical front for the union's first plenary meeting. My paper emerged after detailed discussions with the accountable functionaries and is therefore the result of collective work - a result which all of the leading members of the union agree with and identify." See Barvík, Skladatelé, 5. Vojtěch remarked that these lines were a clever "gangstermafia" tactic: Barvík had written the speech entirely on his own and that, by insisting that it was a collective effort with which everyone agreed, he knew that any dissenters who voiced their views could count on repression. Svatos, Interview with Ivan Vojtěch. 


\section{The Artist's Role in the Cold War Struggle}

Barvík's speech is divided into three relatively equal-sized portions throughout which he cycles a number of modalities to make his points clear. Emerging at the opening is an East vs. West dichotomy, where the socialist utopia being cultivated at home under the patronage of the Soviet Union is brought into dramatic comparison with the sick and declining West led by America. To support this idea, Barvík presents a statistical enumeration of the successes of the national economy during the period 1948-49, or the period after the February 1948 coup, otherwise known as the "Victorious February." Concerning the industrial sector, he boasts "a 3\% increase in mining, a 9\% increase in metallurgy, a 10\% increase in energetics, and a $12 \%$ increase in the metalworking industry." ${ }^{30}$ Regarding the successes of the agricultural sector, he claims that "our children drank 22\% more milk, and we ate 34\% more eggs and 93\% more pork." ${ }^{31}$ And on distribution to the agricultural collectives, he praises the delivery of " 5,500 tractors, 5,900 tractor ploughs, and 2,000 reaper-binders." ${ }^{32}$ To summarize the situation in relation to the enemies in the West, he states that "these numbers provide clear testimony about the unstoppable expansion of our economy and testimony to the fact that our working man, emanating values for everyone, knows how to run the economy much better than the capitalist, who thinks only about profit, his wallet, and how to easily enjoy and extort from the work of others."33

The outsider expecting that an address to a composer's union will be a more purely musical discussion might be surprised by the fact that rhetoric of this kind regarding economics dominates the entire first portion of his speech. But from Barvík's socialist point of view, cultural production is to be an outgrowth of the proletariat, whose most basic needs must first be secured. Once the needs of the proletariat are met and the oppressive forces of capitalism overcome, artists and intellectuals will be free to create and help sustain a truly democratic society. This, in fact, is the nature of "progress," where the "working majority" is in complete control. Barvík brings this into contradistinction with the "reactionary" forces of the First Czechoslovak Republic (1918-1938), otherwise known as the "Bourgeois Republic." It was during the bourgeois years that an "extortive minority" was in power, one that reaped the benefits from their dominating position at the expense of the ordinary man:

Our undeniable economic superiority is further along such that, in comparison with the capitalist First Republic and today's capitalist states, we have undoubtedly come further-and ahead. Fifteen years ago, our large towns were filled with beggars, 300,000 children went to school hungry according to the administrative statistics, unemployed professors went to sweep the streets due to hunger, people committed theft and violations-even misdeeds and crimes just so they could warm themselves up in prison and get fed; fifteen to twenty years ago displaced and hungry people took to the streets to participate in hunger marches and the government cured them of their impoverishment with the volleys of state troopers. Let us just recall Radotín, Duchcov, Krompachy, and the many other places of public murder. Yes, today the son of a national company's general director does not have two English tutors and whatever else he could dream up, yet in our country there is not a child going hungry, and without exception, each one will get an apple in the winter, a regular share of oranges, and of course everything else he needs for his growth. ${ }^{34}$

\footnotetext{
${ }^{30}$ See Barvík, Skladatelé, 7.

${ }^{31}$ Ibid.

${ }^{32}$ Ibid.

${ }^{33}$ Ibid., 7-8.

${ }^{34}$ Ibid., 11.
} 
From this passage, it might seem that all was won with the Victorious February. But Barvík exhorts composers to remain vigilant, as the reactionary forces of the First Republic are still latently active in society. Indeed, efforts must intensify and composers must reconsider how they too can help secure conditions for the final and definitive battle: they must learn to identify and help crush the forces of reaction, "capture the pathos of the Stalinist era," and "set the nation singing" with progressive socialist values. ${ }^{35}$

Barvík's reeducation of musicians continues with a closer examination of contemporary Western and Soviet cultural production. ${ }^{36}$ The Western bourgeois countries have demonstrated nothing other than the kind of degeneration and decline that is indicative of their unjust societies. ${ }^{37} \mathrm{He}$ claims that everything truly great in Western art grew from a battle against capitalism and for a better social order. Such artistic works stand on the side of progress, but for the most part, nothing really great will be found in the reactionary camp aside from an "extraordinarily large heap of decadent art and pornographic literature." 38 To elucidate the situation in France, Barvík relies on a contribution to the communist magazine Var by Jaroslav Bouček, who characterizes French production as a "bottomless swamp" replete with "deranged and sadistic people, prostitutes, thieves, murderers as well as lunatics who torment, rape, rob, and murder each other, whether in the backdrop of a cave, palace, brothel, or gothic castle." ${ }^{39}$

For his scolding of the U.S., Barvík relies on Vladimír Pozner's anti-American tract Divided States, ${ }^{40}$ where culture is seen as a purely monetary enterprise with complete disregard for art's nurturing potential. ${ }^{41}$ For his discussion of the American music scene in particular, Barvík quotes a number of passages that had "slipped out" from the pen of the musical organizer and composers' rights lawyer Jan Löwenbach, who Barvík insists "cannot be suspected of prejudice against America." ${ }^{42}$ Indeed, Löwenbach, like his friend and one-time artistic collaborator Bohuslav Martinů, chose to reside in America after the communist take-over, a treasonous act against the state. Yet in his book Music in America, ${ }^{43}$ Löwenbach had made numerous "veracious" remarks about how music in the U.S. had become an object of exploitation by publishers, arrangers, theaters, the radio, gramophone factories, and even soap factories; how Toscanini conducts Wagner excerpts at cutthroat tempos just to please the public; how the film composer's imagination has been destroyed by the demands of Hollywood; how opera houses cater only to the rich and have no select repertoire; and how the fate of musicians and musical culture in general has been left in the hands of private initiative without any federal, state, or municipal subvention. ${ }^{44}$ Barvík summarizes Löwenbach's statements in Zhdanovite terms by writing that, "indeed, the commerciality and immorality

\footnotetext{
${ }^{35}$ See ibid., 12-13, and 24-25.

${ }^{36}$ Ibid., 13-18.

${ }^{37}$ Ibid., 14.

${ }^{38}$ Ibid., 14.

${ }^{39}$ Ibid., 14-5. Barvík is quoting from Jaroslav Bouček, "Dva tábory v boji o francouzskou kulturu" ["Two Camps in the Battle over French Culture"] Var 3, no. 2 (1 Apr. 1950): 42-53. As examples of works saturated with such psychopathic characters, Barvík (via Bouček) cites Boris Vian's Let the Corpse Dance and I Spit on Your Graves as well as Hervé Bazin's Viper in the Fist and Head against the Wall. With the first title by Vian, Barvík's reference might be to the French author's Les morts ont tous la même peau.

A Czech cultural journal of leftist, or "progressive" political persuasion, Var was published by Zdeněk Nejedlý during the years 1921-30; Nejedlý served as editor during the years 1948-53 when it was reestablished towards the goal of helping develop socialist culture. The name of the journal could be translated roughly as "Ebullition," or "At the Boiling Point."

${ }^{40}$ See Vladimír Pozner. Rozpojené státy [Divided States] (Prague: Nakladatelství Svoboda, 1949).

${ }^{41}$ Barvík, Skladatelé, 15-6.

${ }^{42}$ Ibid., 16.

${ }^{43}$ See Jan Löwenbach, Hudba v Americe [Music in America] (Prague: Hudební matice Umělecké besedy, 1948). Löwenbach, under the pseudonym J.L. Budín, wrote the libretto to Martinů's opera The Soldier and the Dancer (1927).

${ }^{44}$ Barvík, Skladatelé, 16-8.
} 
of bourgeois art has had the following results: anationality, cosmopolitanism, an absence of ideas, formalism." 45

Barvík then extols Soviet cultural production, which has become the sustenance of the new people, and he enumerates several Soviet novels and films through which Czechs and Slovaks can now educate themselves. ${ }^{46}$ These works, according to Barvík, reflect the attributes of the "camp of peace," which include "a strength of ideas, a high morale, as well as a fostering of fairness, honesty, and dignity." 47 Indeed, the Soviet Union has shown how artists can serve socialist ideals, and it is necessary for Czechoslovak composers to follow in its example. ${ }^{48}$ That the modern composer can help foster socialism rather than conform to the demands of the Catholic Church, the aristocracy, or the bourgeoisie is the basic transvaluation of the new musical culture. There are notable examples of how musicians served great ideals in the past, such as Beethoven and his vision of man's liberation from feudal bondage and Smetana's devotion to the national revival and liberation. Beethoven and Smetana were heroes of past oppression, and the contemporary composer too should not be afraid to serve a higher social order. Remarking in the "optimistic" spirit of Zhdanovite socialist realism, he writes, "who among us sees a limitation of creative possibilities by writing about happiness, beauty, the truth, a better mankind, and happy children?"49 And with the intensified battle against the capitalist West and the power of the state in hand, artists and scholars now have the chance to embrace this challenge and place their entire creative efforts in insuring victory for the global socialist cause.

\section{Music during the "Bourgeois Republic"}

The second portion of Barvík's speech reevaluates the music of the First Czechoslovak Republic.$^{50}$ It gives us a chance to see how the communist musicologists married Soviet artistic policy with the socialist view of Czech music history. To understand this segment, it is important to clarify a number of concepts that Barvík relies upon-concepts that have their roots in a valuation system that began with the nineteenth-century aesthetician Otakar Hostinský and continued in the early twentieth century with Zdeněk Nejedlý. ${ }^{11}$ By the time of Barvík's speech, Nejedlý-the most important socialist music critic of the First Republic —now presided as Minister of Education, a post he held until $1953 .^{52}$

\footnotetext{
${ }^{45}$ Ibid., 18. Here the subtext to an "absence of ideas," i.e., "formalism," is the absence of the right ideas, or those consistent with Soviet artistic policy.

${ }^{46}$ Ibid., 18-19. The Soviet novels that Barvík cites include Polevoy's Story of a Real Man, Fadejev's The Young Guard, and Ehrenburg's The Storm; the Soviet films include The Academic Ivan Pavlov, The Battleship Potemkin, and The Battle of Stalingrad. For more on the Zhdanovite films and literature, see Werth, 9-16.

${ }^{47}$ Barvík, Skladatelé, 19.

${ }^{48}$ Ibid., $19 \mathrm{ff}$.

${ }^{49}$ Ibid., 20.

${ }^{50}$ Ibid., 25-40.

${ }^{51}$ For more on the Hostinský-Nejedlý aesthetic lineage in the context of earlier generations of musical debate, see Brian S. Locke, Opera and Ideology in Prague: Polemics and Practice at the National Theater, 1900-1938 (Rochester: University of Rochester Press, 2006), 22-64.

${ }^{52}$ By this period, Nejedlý, more of a symbolic figurehead, was far less involved in the battle over music culture, leaving this almost entirely in the hands of the young ideologues Barvík, Antonín Sychra, and Jaroslav Jiránek. For a fine study of Nejedlý during the communist period, where he is revealed as both uncomfortable and inept in the highest-ranking circles of communist power, see Jiří Křest’an, “"Poslední husita' odchází. Zdeněk Nejedlý v osidlech kulturní politiky KSČ po roce 1945” [“"The Last Hussite' Departs: Zdeněk Nejedlý in the Snares of CCP Cultural Politics after 1945"] Soudobé dějiny 12, no. 1 (2005): 9-44.
} 
One of the most important criteria for Barvík's appraisal of musical works is "ideovost," a notion that has its origins in the first serious studies of Bedřich Smetana and which can be translated here simply as "programaticism." Smetana's early defenders, who were led by Hostinský, found Smetana's oeuvre replete with themes that were designed to raise national conscience, and for this reason considered his output the programmatic foundation of modern Czech music. With the fulfillment of the nation-building process through "Czechoslovak" sovereignty in 1918, the call for national ideovost began to gradually merge with the demand for socialist ideovost, a process led by Nejedlý throughout the First Republic years. What had triggered the desire for ideovost with a socialist agenda was the disenchantment of those on the left, who thought the new state would follow the path of Russia's "great October Revolution," or the path that is "evolutionary, peaceful, and developmental." ${ }^{53}$ But with the "bourgeois seizure of power" in December 1920 , the central tenet of the communist platform became the destruction of the new state and the liberation of the working class from capitalist tyranny. Many composers chose to join in this struggle by writing works that addressed the plight of the working class-heroic efforts that Barvík honors throughout the third portion of his speech. ${ }^{54}$ It is important to realize, therefore, that for several decades before 1948, creating a working class identity through musical works had been well-represented in Czech critical culture, and that upon the "Victorious February," ideologically synchronizing pre-war socialist efforts with the demands of Soviet socialist realism was not such a major leap.

As a result of the "misguided structures" of bourgeois society, the First Republic was a sharply divided world, apparent from the superstructures of musical production of that time. On the one hand, there were continuators of the programmatic tradition, and then others who had fumbled along regressive paths. Barvík uses a number of pejoratives to describe the latter kind of composer: for not continuing along the nationally programmatic stream, the composer was cosmopolitan; for not addressing, educating, and serving the widest possible audience with comprehensible works, he was a formalist; and for not embracing the progressive vision of a new socialist society governed by the working class, he was a reactionary. It is important to note that the communist notion of progress is irreconcilable with the Western notion of musical modernism, which can be defined as the desire by composers to create systems and styles that reflect the technological transformations of the day. ${ }^{55}$ In communist valuation, however, works that impose systems and styles that are foreign and unpalatable to the general audience are reactionary and formalist, and as a result of producing such works, which Barvík censures simply as "experiments," the musical artist becomes alienated from the working masses, who are left with no moral guidance as to how they can better deal with capitalist oppression. ${ }^{56}$ To illustrate how composers have blundered into reactionary formalism, Barvík draws on the writings of Igor Stravinsky, who had confessed the following about the relationship between the modern artist and the public:

A complete agreement is all the more rare when the author's personality expresses itself more clearly. The more (the artist) eliminates everything that comes from without, or everything that is not him and what is not "inside of him," the more he disappoints the expectations of the wider audience, because people are restrained by everything that is unusual to them. ${ }^{57}$

\footnotetext{
${ }^{53}$ Barvík, Skladatelé, 27.

${ }^{54}$ Ibid., 27.

${ }^{55}$ See Leon Botstein, “Modernism” The New Grove Dictionary of Music and Musicians, 2nd Edition (2001), 16: 868-875.

${ }^{56}$ Barvík writes, "This proves the entire deep divide between the individual and society, the intention of the bourgeoisie to isolate people, to confuse them - to isolate the artist!" See Barvík, Skladatelé, 34.

${ }^{57}$ Ibid., 18.
} 
The implication of this remark is that-by choosing formalism over progress-Stravinsky has become an agent of the ruling class, whose principal objective is to keep the proletariat disenfranchised politically:

This is why we understand formalism today as an instrument in the hands of the bourgeoisie against the programmatic progress of ideas. ${ }^{58}$

We may now turn to Barvík's appraisal of specific composers and see how two of the most important living personalities of Czech musical culture-Bohuslav Martinů and Alois Hába-became the primary targets of his revisionist criticism.

Among the continuators of national ideovost, Barvík first honors Josef Bohuslav Foerster, who had returned to his homeland patriotically after twenty-five years abroad, as well as the "great school" of Vítězslav Novák. ${ }^{59}$ It was Novák, in fact, who had instigated the establishment of the Society for Modern Music in 1921, which then transformed into the Czechoslovak chapter of the ISCM. ${ }^{60}$ But according to Barvík, Novák gradually distanced himself from the Czechoslovak ISCM chapter because he "recognized the aberrant nature of its paths which left the field free for composer-experimenters." ${ }^{61}$ And among the most prominent experimenters of the new society, Barvík cites Ernst Křenek, ${ }^{62}$ as well as the pioneer of microtonal music, Alois Hába.

Barvík then turns his attention to the destructive influences of cosmopolitan Paris, which placed Bohuslav Martinů into the line of fire. ${ }^{63}$ From the time of his arrival in Paris in 1923, Martinů had become an enemy to the socialist music critics due not only to a number of works demonstrating the influence of the Parisian milieu, but also through a series of essays in which he called for greater experimentation, a better understanding of what was happening in the French capital, and the recognition of Igor Stravinsky's monumental significance. ${ }^{64}$ All of these values provided grounds for reprimand. But now, with Martinů a permanent resident of the U.S., Barvík adds heat to the flames by drawing attention to several other offensives made by a composer who had disregarded the nationalist-socialist programmatic stream, i.e., for studying in France with the aid of a stipend from the First Republic's government, for prolonging his residence abroad, for plagiarizing foreign styles, and for simply selling out to the West. Barvík writes:

The first to be allured by Paris was Boh. Martinů-the great expert and admirer of Stravinsky. He even received a state scholarship for his studies in Paris. And he has remained abroad until this very day. It was the time of the great boom in the so-called "catching up with Europe" and soon [after his arrival] Martinů introduces himself [to the Czech public] with his orchestral

\footnotetext{
${ }^{58}$ Ibid., 33.

${ }^{59}$ Ibid., 28.

${ }^{60}$ Ibid., 28.

${ }^{61}$ Ibid., 28-9. An interesting subject for further study is how Barvík, undoubtedly as an expression of regional pride, elevates his fellow Moravian composers throughout his speech, i.e., Novák, Kaprál, Kaprálová, etc. The fact that Nejedlý had attempted to bypass Leoš Janáček in the national musical history required Barvík to assess this particular Moravian composer more critically. Later in his career, Barvík championed Janáček.

${ }^{62}$ Ibid., 29. It is interesting to note that, even twenty-five years after the fact, the Czechs were still strangely co-opting and (simultaneously) disowning Křenek as one of their own, all because of the Czech diacritic in his name. By this point the Austrian composer had taken up residence in the U.S. and was probably unaware of the debate to which he still belonged in Prague. See Locke, 122.

${ }^{63}$ Barvík, Skladatelé, 29.

${ }^{64}$ I have attempted to define Martinůs place in inter-war Czechoslovakia in Thomas D. Svatos, "A Clash over Julietta: the Martinů/Nejedlý Political Conflict and Twentieth-Century Czech Critical Culture,” ex tempore, 2009 and Martinu on Music and Culture: a View from his Parisian Criticism and 1940s Notes (UC, Santa Barbara, 2001), 1-75. Both studies examine how French influence was used against Martinů by the Czech socialist music critics.
} 
compositions "Half-time" and "La Bagarre" from which it became clear that he had discovered the motorism and constructivism of Stravinsky. It is music that is indistinguishable from Honegger's Pacific and in compositional technique-a complete copy of Stravinsky.

It was with this musical chaos that Martinů presented himself on American soil, it was through these compositions that Koussevitsky discovered him, it was through these compositions that he gained his first great success in Boston and through which he received the attention of foreign publishers. This was his path to world fame. ${ }^{65}$

Zdeněk Nejedlý, on the other hand, a "truly progressive spirit," saw the new state's future in Moscow rather than Paris and established The Society for the New Russia. ${ }^{66}$ And as early as 1923, Nejedlý had shown the futility of experimentation: on the subject of melody, for example, Nejedlý wrote that new attempts at melodic conception "will only be found once we begin living the new life that our era is giving birth to [...] for this reason, playing games with quarter-tones is not a response to a world that is new, but rather to the one that is old and dying away." 67

By citing Nejedlýs criticism of microtonal music, Barvík sets the stage for his revision of Alois Hába and the formalist theorists of the Bourgeois Republic who had declared Hába's work to be the most advanced development in Czech music. ${ }^{68}$ Barvík draws on the writings of Hába's student, Karel Reiner, ${ }^{69}$ who considered Hába to be the foremost proponent of the "dubious" philosophical stream of anthroposophy, ${ }^{70}$ and shows amazement that a progressive intellectual such as the one-time Nejedlý student Vladimír Helfert could be so affected by formalist aesthetics to place Hába at the end of a distinguished line of Czech composers that began with Smetana. ${ }^{71}$ Barvík notes the quarter-tone system and athematicism as regressive traits in Hába's work and states that such styles can provide neither revolutionary incentive nor response. ${ }^{72}$ And Barvík is particularly remonstrative of Hába's opera The New Land, where a mother gnaws away at the bone of her dead child during the exposition and during which the composer later cites the Internationale - the crudest combination of elements embodying nothing less than slander against the Soviet Union. ${ }^{73}$

Martinů emerges once again in the discussion of musical production during the 1930s. But this time, after a few remarks about the misguided aspirations of the Slovaks, Barvík contrasts Martinů with a number of more socially progressive composers:

The 1930s brought great clarity to the situation in our music, when the new Slovak generation, seduced by Prague, begins allegedly "to catch up with the world" and "opens up a window to Europe" (although it has treasures of folk creativity at home that have not yet been appraised) and when the battle against the fascist menace nevertheless unites many artists with the camp of progress. And thus we see that, while Boh. Martinů writes his "Plays of Mary" and leads

\footnotetext{
${ }^{65}$ Barvík, Skladatelé, 29.

${ }^{66}$ Ibid., 30.

${ }^{67}$ Ibid., 30.

${ }^{68}$ Ibid., 32 ff.

${ }^{69}$ For more on Reiner, see Milan Kuna, Dvakrát zrozený. Život a dílo Karla Reinera [Twice Born. The Life and Works of Karl Reiner]. (Prague: $\mathrm{H}+\mathrm{H}, 2008$ ).

${ }^{70}$ Here it is Barvík who is skeptical of anthroposophy, not Reiner.

${ }^{71}$ Barvík, Skladatelé, 34-38.

${ }^{72}$ Ibid., 39.

${ }^{73}$ Ibid., 39. In his condemnation of Hába, Barvík makes the disclaimer that, "I would like to point out that we are dealing with Al. Hába as an historical phenomenon, as a one-time representative of a certain part of Czech music, or someone who is completely different from the Prof. Hába and his efforts today." See Ibid., 37. Hába's half-tone opera The New Land (1936) - yet to be performed to this day - deals with the Holodomor, or the Ukrainian famine of 1932-33.
} 
listeners' attention away to the middle ages, Ostrčil composes "Johnny's Kindom," Vomáčka "The Guards of the Lighthouse," and even someone like the one-time hardened formalist and typical cosmopolitan Ervín Schulhoff reverses the direction of his work to a new, clear goal and attempts to set the "Communist Manifesto," [and we see that] Vítek Nejedlý writes scenic music for revolutionary worker plays and Stanislav holds discussions in the Soviet Union about his "Granada." 74 The battle against the occupiers intensified the positions of the two camps and brought more artists into the camp of progress, even though the effects of pseudo-art and formalism became detrimentally attached to many fighters in their struggle against the fascists. ${ }^{75}$

Towards the end of his revisionist discussion, Barvík plays musical excerpts to the assembly in order to demonstrate reactionary and progressive attributes of more recent works. ${ }^{76}$ Barvík first nods to tradition by playing an unnamed polka by Smetana, which he follows with Karel Reiner's Piano Sonata No. $2^{77}$ from 1942:

\section{Audio EXAMPle 1: Karel Reiner, Piano Sonata No. 2, Mov. I, opening.}

Accessible at: http://dx.doi.org/10.3998/mp.9460447.0004.101

Performed by: Cezary Kwapisz

Recording courtesy of Anke Zimmermann

Barvík states, "Is this really progress? Is this cacophony-in comparison with Smetana's joy and optimism - the kind of progress with which we can possibly proclaim the music of the new age? And isn't 'Polka,' written by Václav Dobiáš in 1950, a genuinely progressive composition?"78

It is unclear which Dobiáš composition Barvík chose to play at this moment, but two of Dobiášs works from this time are possible. If it was one of the Three Poetic Polkas for solo piano, the work displayed a "return to Smetana" as a sign of progress. ${ }^{79}$ But more likely than not, Barvík's selection was the cantata for mixed chorus and orchestra Build Up Your Country to Reinforce Peace! A Czechoslovak Polka, ${ }^{80}$ which demonstrated stylistic allegiance to Smetana, the pathos of the Soviet mass song style, and the communication of both nationalist and socialist ideals through the text:

\footnotetext{
${ }^{74}$ Josef Stanislav (1897-1971) was a composer and propagator of socialist-realist genres, in particular the mass song. Barvík's reference is to Stanislav's cantata about the Spanish Civil War Píseň o Granadě [Song about Granada].

${ }^{75}$ Barvík, Skladatelé, 31.

${ }^{76}$ Ibid., 38 ff.

${ }^{77}$ Ibid., 38-9. Karel Reiner, Sonata No. 2 for Solo Piano, Melantrich (Prague: 1947). Vojtěch remarks that singling out Reiner had been an especially rude gesture, as the Czech-Jewish composer had been imprisoned by the Nazis in the Terezín concentration camp. See Svatos, Interview with Ivan Vojtěch. For more on this composition, composed by Reiner just before his deportation, see Kuna 132-36.

${ }^{78}$ Barvík, Skladatelé, 39.

${ }^{79}$ Václav Dobiáš, Tři poetické polky pro klavír [Three Poetic Polkas for Piano] (Prague: Orbis, 1950).

${ }^{80}$ Václav Dobiáš, Buduj vlast - posilíš mír!, československá polka [Build Up Your Country to Reinforce Peace! A Czechoslovak Polka] (Prague, Orbis 1950).
} 


\section{Audio EXAMPle 2: Vaclav Dobiáš, Build Up Your Country to Reinforce Peace! A Czechoslovak Polka.}

Accessible at: http://dx.doi.org/10.3998/mp.9460447.0004.101

Performed by: Karel Ančerl and the Czech Philharmonic Orchestra (Supraphon, 1951)

Text: We, Czech and Slovak people, promise from the bottom of our hearts to answer loyally the call of duty given to all of us by our country.

Barvík's decision to play this work at this moment helped crown Dobiáš as the paradigmatic Czech communist composer of the time. Other works by Dobiáš that are consistent with Barvík's prescription for the new music include the cantatas Stalingrad and Stalin's Order No. 368 of 9 May $1945 .{ }^{81}$

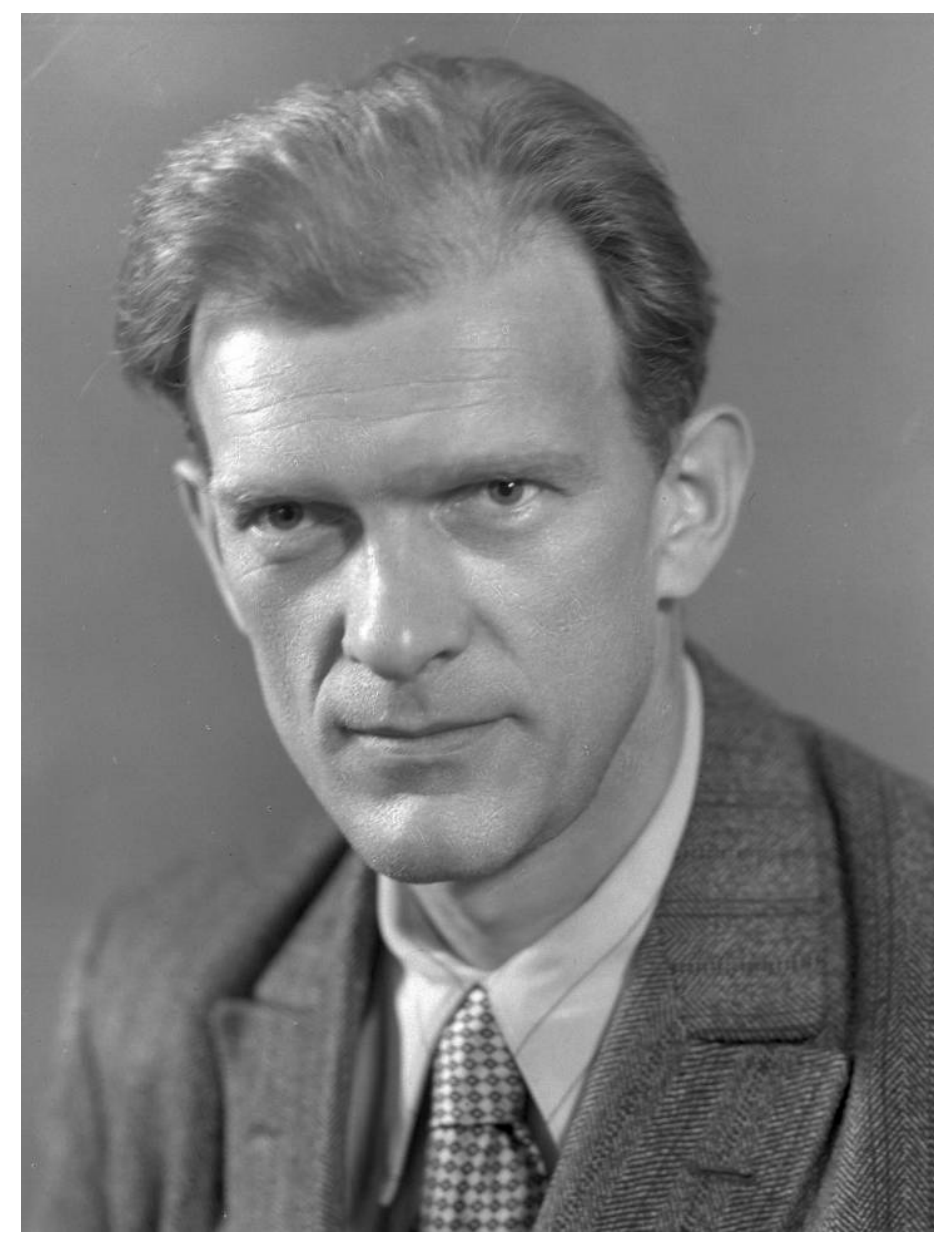

Figure 3. Václav Dobiáš, 18 August 1950.

\footnotetext{
${ }^{81}$ For a more recent critical study on Dobiáš, see Geoffrey Chew, "Václav Dobiáš’s Celebration of Proletarian Prague: The Song Cycle Praho jediná," Socialist Realism and Music, ed. Mikuláš Bek, Geoffrey Chew, and Petr Macek (Prague: Koniasch Latin Press, 2004), 214-223. The standard, communist-era monograph on Dobiáš is Jiř́ Štilec, Václav Dobiáš (Prague: Panton, 1985).
} 


\section{Music of the Socialist Future}

In the third portion of his speech, Barvík provides specific instructions on the subjects and styles Czech composers should embrace. ${ }^{82}$ His discussion is organized by genre. He continues with his revisionist commentaries about formalist works of the past, comparing them with the progressive efforts of the past, present, and socialist future. It is his final effort to crystallize a canon of Czech communist works and the compositional philosophy of the new socialist state.

Barvík begins with the song production of the First Republic, criticizing "serious" composers for deforming melody to the point of being unsingable and the commercial composers of mostly inferior rank who produced formulaic songs for monetary gain. ${ }^{83}$ He praises the songs of Jaroslav Ježek for the important role they played in the battle against fascism, and the worker songs of Josef Stanislav and "Vítek" Nejedly. ${ }^{84}$ Regarding the situation after the war and particularly after 1948, he takes pride in the surging production of mass songs that "are now being sung by thousands of young people." ${ }^{85} \mathrm{He}$ is otherwise remonstrative of the cosmopolitan influences of America, Paris, and Vienna during the 1920s and claims the situation was finally saved in the 1930s when Soviet songs began to "victoriously push out commercial trash." ${ }^{86}$ He marvels at the monumental task ahead for contemporary composers to produce songs that will nurture socialist patriotism in miners, soldiers, pioneers, agricultural workers, and children. ${ }^{87}$ And he reminds the assembly not to neglect hymns popularizing the proletarian efforts of women and the "úderníks," or those exemplary workers whose performance should be venerated by the nation. ${ }^{88}$

He then turns to choral music, which he considers one of the most progressive genres of the First Republic and the one that did the most to transmit proletarian poetry. ${ }^{89}$ Composers need to guard against formalism, however, as they have had the tendency to write excessively technical works which few ensembles can perform. ${ }^{90}$ Barvík notes that there are now undreamed of possibilities in writing choral works for worker and youth organizations and that many factories would gladly employ a union musician to help them raise the level of their worker ensembles. ${ }^{91}$

Regarding opera, he reminds the assembly about the pronouncements of Zhdanov, who "revealed the entire problem of decline in opera and pointed out the path towards revision," but he offers no details about the Soviet ideologue's pronouncements. ${ }^{92}$ Nevertheless, he calls for a "similar" self-examination in Czech production. Opera suffered a notable decline during the First Republic by having lost its

\footnotetext{
${ }^{82}$ Barvík, Skladatelé, 40-64.

${ }^{83}$ Ibid., 40 ff.

${ }^{84}$ Ibid., 40-1. Vít Nejedlý (1912-45), conductor and composer of socialist music and son of Zdeněk Nejedlý, died on the eastern front during the last phases of fighting in World War II. Barvík is showing affection for the Education Minister's fallen son by using the diminutive "Vítek."

${ }^{85}$ As top composers of the mass song, Barvík commends Václav Dobiáš, Jan Seidl, Josef Stanislav, Jan Kapr, Jiř́ Pauer, Radim Drejsl, and Vladimír Sommer. See Ibid., 41.

${ }^{86}$ Ibid., 41-2.

${ }^{87}$ Ibid., 42-3.

${ }^{88}$ Ibid., 42-3. The term údernik (shock worker) came to Czechoslovakia from the U.S.S.R. It was a worker who extraordinarily surpassed fixed working norms and was to be an example to others. However, it was usually fraud that served above all as a pretext for raising expectations for work output, because the úderníks more often than not adhered neither to technological nor safety procedures and thus omitted the various preparatory tasks that were encompassed in a particular quota. For more on the úderník and the concepts of Czechoslovak communist culture, see Vladimír Macura, Štastný vék. Symboly, emblémy a mýty 1948-1989 [The Happy Period: Symbols, Emblems, and Myths 1948-1989] (Prague: Pražská imaginace, 1992).

${ }^{89}$ Barvík, Skladatelé, 43-45.

${ }^{90}$ Ibid., 43-44.

${ }^{91}$ Ibid., 44-45.

${ }^{92}$ Ibid., 45-47. For Zhdanov's pronouncements on opera, see Werth, Musical Uproar.
} 
connection with the national tradition and ceased being a form that could arouse the people's conscience and thus lead the nation. A case in point is Leoš Janáček, whose earlier operas contained progressive social commentary: in Jenůfa, for example, Janáček shows the societal divisions of village life; in The Travels of Mr. Brouček, he provides a caricature of the Czech burgher; and in The Cunning Little Vixen, he pokes fun at the entirety of bourgeois society. ${ }^{93}$ In Kát’a Kabanová, however, Janáček misunderstood the fundamental dilemma of Ostrovsky's drama as well as the entire era in which he lived. ${ }^{94}$ Through his subjective reading of the suicide-driven Kát’a, Janáček elevated the tragedy of the individual and expunged from the work the important class divisions that are fundamental to the original drama. ${ }^{95}$ And in his final works, Janáček went astray by focusing on the hopelessness, pessimism, and futility of human behavior, thus arriving at a dead end in musical style. ${ }^{96}$ Regarding his prescription for opera, Barvík calls for the depiction on stage of the new socialist man and for the creation of Hussite operas that will radiate progressive revolutionary values. ${ }^{97}$ Here Barvík has in mind the popular communist notion-fostered largely by Zdeněk Nejedlý-that the Roman Catholic Church's extortion from the peasantry during the middle ages is analogous to the bourgeoisie's exploitation of the proletariat and that the modern Czech composer should portray the Hussite uprising against Rome as a kind of proto-communist movement. ${ }^{98}$

Barvík then grills the First Republic's operetta repertoire and provides a year-by-year enumeration of the smutty and immoral works that Prague's theaters forced on the public. ${ }^{99}$ He pans Weinberger's Švanda the Bagpiper as the work of a scribbler that has no place in the national tradition and should have never received recognition abroad as a characteristic Czech work. ${ }^{100}$ Indeed, light musical theater went through dire straits during the bourgeois years and there is now hardly any tradition upon which to build. Contemporary composers need to collaborate with writers to create light and optimistic works portraying the transformation of man in the new economic conditions. ${ }^{101}$ And as a challenge to his audience as to who will create the great socialist sequel to Smetana's immortal village comedy, he exclaims, "our entire public waits with suspense as to who among you composers will arrive first and succeed in writing today's Bartered Bride!"102

Cantata production was remarkably strong during the bourgeois years, but Barvík notes that creative strength was somehow insufficient to show the greatness of the nation's struggle and that composers were unable to continue the venerable tradition that began with Smetana's warm and rejoiceful Czech Song. ${ }^{103}$ Indeed, the spirit of the cantata during the 1920s began to meander, as elements of subjectivism, mysticism, and symbolism began to permeate works that lost touch with the masses. ${ }^{104}$ It was at this time, for example, "during the proletariat's fierce struggle with the bourgeois minority," that Ladislav Vycpálek composed About the Last Matters of Man but when the poet S.K. Neumann "called the people into battle

\footnotetext{
${ }^{93}$ Barvík, Skladatelé, 45.

${ }^{94}$ Ibid., 45.

${ }^{95}$ Ibid., 45.

${ }^{96}$ Ibid., 45.

${ }^{97}$ Ibid., 47.

${ }^{98}$ I have yet to find an example of a Hussite opera, but the followers of the early fifteenth-century Czech theologian are clearly shown in this light in the film trilogy Jan Hus—Jan Žižka-Proti všem. Vávra, Otakar, Dir. (Prague: Studio uměleckých filmů, 1954, 1955; Filmové Studio Barrandov, 1957).

${ }^{99}$ Barvík, Skladatelé, 47-49.

${ }^{100}$ Ibid., 49.

${ }^{101}$ Ibid., 49.

${ }^{102}$ Ibid., 49.

${ }^{103}$ Ibid., 49-51.

${ }^{104}$ Ibid., 50.
} 
which ended with the definitive liberation of man and the foundations for the new life." ${ }^{105}$ And Barvík reminds the audience about the great example of Stanislav's Song about Granada, a "hymn from 1936" about the battle of the Spanish people which "even aroused discussions in the Soviet Union" but was rejected by the bourgeois critical establishment in Czechoslovakia as an "impetuous street brawl that has no place on the concert podium." 106

His verdict on symphonic production during the bourgeois years is negative on the whole, as the orchestra had become "a free field for experimenters whose works lacked programmatic ideas." 107 As a result, the symphonic composer became a specialist in racket and novel sound combinations to the detriment of pure idiomatic sonority. But the situation was not so one-sided. Barvík writes, "let us just recall some of the masterworks by Ostrčil, Schulhoff's battle with the legacy of formalism in his Symphony of Freedom, ${ }^{108}$ works by Vítek Nejedlý particularly from his residence in the U.S.S.R., Vítka Kaprálová, ${ }^{109}$ The Red Army Symphony by Josef Stanislav, and the many other compositions in which authors strove for new content that was expressed by realistic music that relied on the development of melody." Regarding the new symphonic works, Barvík asserts that they should continue in the great tradition of Smetana's Má vlast and strive to express "the joy in building the new life, the greatness of our national heroes, the heroes of battle, labor, and so forth." 110

Then Barvík comments on a number of different areas: he criticizes chamber music as another arena of the formalist experimenter, ${ }^{111}$ folk song for having become relegated to the museum or commercial exploitation due to its neglect by composers, ${ }^{112}$ and the fields of theory, education, and criticism for becoming disconnected from practice and insufficiently guiding musical debate. ${ }^{113}$ Sustaining the greatest burden of disapproval here is the theorist-composer Karel Janeček. ${ }^{114}$ As an example of the formalist chamber music, Barvík plays Janeček’s Tema con variazioni for solo piano, ${ }^{115}$ a work demonstrating "melodic deficiency," "burdensome impotence," and "harmonic confusion." "116 And Janeček could not even sidestep his penchant for formalism in his instructional works for young musicians. To illustrate his point, Barvík plays a Janeček waltz for solo piano from 1926, which "had been even carefully edited by a noted expert."117

\footnotetext{
${ }^{105}$ Ibid., 50. Barvík cites Jiří Wolker (1900-1924) as an exemplary Czech author whose poetry served numerous socially conscious cantatas. As an example of a cantata on a Wolker text, Barvík cites Vilém Petrželka's Námořník Mikuláš [Mikuláš the Sailor]. Wolker, along with Stanislav K. Neumann (1875-1947), had just been consecrated three months earlier (in January 1950) at the foundation of the official cannon of communist poetry by the top literary ideologue Ladislav Stoll; Stoll's speech to the Union of Czechoslovak Writers, the most influential Czechoslovak artistic union, served as a primary ideological guide for Czech cultural politics at the time. See Ladislav Štoll, Třicet let bojů za českou socialistickou poesii [Thirty Years of Battles over Czech Socialist Poetry] (Prague: Orbis, 1950). S.K. Neumann's place in the communists' cultural canon was solidified by his 1937 tract Anti-Gide, or Optimism without Superstitions and Illusions, which served as the primary Czechoslovak communist rebuttal to André Gide's Return from the U.S.S.R. See Stanislav K. Neumann, Anti-Gide, neboli optimismus bez pověr a ilusí [Anti-Gide, or Optimism without Superstitions and Illusions] (Prague: Vydavatelstvo Družstevní Práce, 1950). S.K. Neumann's origins in the early twentieth-century Czech modernist movement were obscured in new editions of his works in the 1950s.

${ }^{106}$ Barvík, Skladatelé, 51.

${ }^{107}$ Ibid., 51-52.

${ }^{108}$ A reference to Schulhoff's Symphony No. 6, "Symphony of Freedom."

${ }^{109}$ Barvík, Skladatelé, 51. Václav Kaprál's daughter Vítězslava Kaprálová undoubtedly emerged here for her orchestral movement Military Sinfonietta (1938), seen as a symbol of Czechoslovak resistance to Hitler's ultimatums. Her place in the new canon was undoubtedly inspired by Barvík's loyalty to the Kaprál family and his fellow Moravian composers in general. Barvík expresses his affection for Kaprálová by using the diminutive "Vítka."

${ }^{110}$ Barvík, Skladatelé, 52.

${ }^{111}$ Ibid., 53-54.

${ }^{112}$ Ibid., 54-55.

${ }^{113}$ Ibid., $55-57$.

${ }^{114}$ Ibid., 53 and $56 \mathrm{ff}$.

${ }^{115}$ See Karel Janeček, Tema con variazioni, op. 23 (Prague: Hudební matice Umělecké Besedy, 1949).

${ }^{116}$ Barvík, Skladatelé, 53.

${ }^{117}$ Ibid., 53.
} 
Barvík writes that the purported goal of such works was to help accustom students to the dissonant sounds of modern music over time, but in the end, the formalist pedagogues only disgusted their protégés and dissuaded them from further study. ${ }^{118}$

Then Barvík turns to the impact of theory on higher education, where esoteric systems and speculative concepts were forced on students to the detriment of genuine feeling and inspiration. ${ }^{119}$ This holds true for the instruction of harmony, which became prone to the calculated mixing and matching of abstract sonorities. For this Janeček is partially to blame, but also the theorist-composer Zdeněk Blažek. Condescendingly, Barvík writes that Blažek's study on "two-way alteration” is an example of an artist who creates systems for systems' sake which "do not hide their support of formalistic tendencies and which are geared [purely] towards technical and sonic issues." ${ }^{" 20}$ And Barvík notes that Blažek had even defended the necessity of his work on the premise that the Germans had come much further in this area and that he had thus helped facilitate the development of Czechoslovak music. ${ }^{121}$

Barvík's conclusion showcases the leading thinkers who had brought Czechoslovak musical culture to the present day. ${ }^{122}$ He looks to the "other side" of the formalist camp to Otakar Hostinský, whose ideas came to a climax with the work of Zdeněk Nejedlý. ${ }^{123}$ But Nejedlý's efforts as the valiant propagator of Smetana, Jirásek, and other great symbols of Czech culture have yet to be appreciated in full, as he still tends to be viewed through the distorted eyes of the bourgeois class. ${ }^{124}$ It was Nejedlý, in fact, who had "always stood fearlessly at the most exposed positions of the progressive cultural front" and who had "converted his university lecture hall into an assembly for the working masses." ${ }^{25}$ Indeed, Nejedlý does not understand musicology as the explanation of abstract theories, but has shown instead the levers of progress through his studies on the Hussites, Smetana, and Soviet music among others. ${ }^{126}$ In homage to the man upon his seventieth birthday, President Klement Gottwald even wrote that Nejedlý had served as a guardian of the nation's past, because he realized that "the proletariat and the working people are the nation's new leading force and the ones who breed and disseminate the best the nation has ever created." 127

\footnotetext{
${ }^{118} \mathrm{Ibid}$., 53-54. Janeček holds a special place in the history of compositional pedagogy for a method in which students learn to hear complex sonorities through pitch-sets rather than triadic foundations, pre-dating Forte's pitch-set method for atonal analysis by a number of years. For a recent study on Janeček's compositional method, see John MacKay, “An Overview of Karel Janeček's Foundations of Modern Harmony" ex tempore 11, no. 1 (2002): 1-43.

${ }^{119}$ Barvík, Skladatelé, 55.

${ }^{120}$ Ibid., 56. Barvík is referring to Zdeněk Blažek, Dvojsměrná alterace v harmonickém myšlení [Two-way Alteration in Harmonic Thought] (Brno: Rovnost, 1949). On Blažek's life and work, see Lubomír Peduzzi, Zdeněk Blažek. Obraz života a díla [Zdeněk Blažek: A Picture of his Life and Work] (Brno: Kulturní klub NV, 1988); Blažek’s work as a theorist is discussed on pp. 76-80. Among Blažek's later achievements is a two-volume edition of Leoš Janáček’s theoretical works. See Leoš Janáček, Hudebně teoretické dílo [Works in Music Theory], 2 vols., ed. Zdeněk Blažek (Prague: Editio Supraphon, 1968, 1974).

${ }^{121}$ Barvík, Skladatelé, 56.

${ }^{122}$ Ibid., 57-64.

${ }^{123}$ Ibid., 57.

${ }^{124}$ Ibid., 57. For a study presenting a collection of Nejedlý caricatures from the First Republic press, see Eva Paulová, "Obraz jako zbraň bojů o Dvořáka a Smetanu" ["The Picture as a Weapon in the Battles over Dvoř́a and Smetana"] Opus musicum 34, no. 1 (2002): 21-26.

${ }^{125}$ Barvík, Skladatelé, 57-58.

${ }^{126}$ Ibid., 59-60.

${ }^{127}$ Ibid., 58.
} 


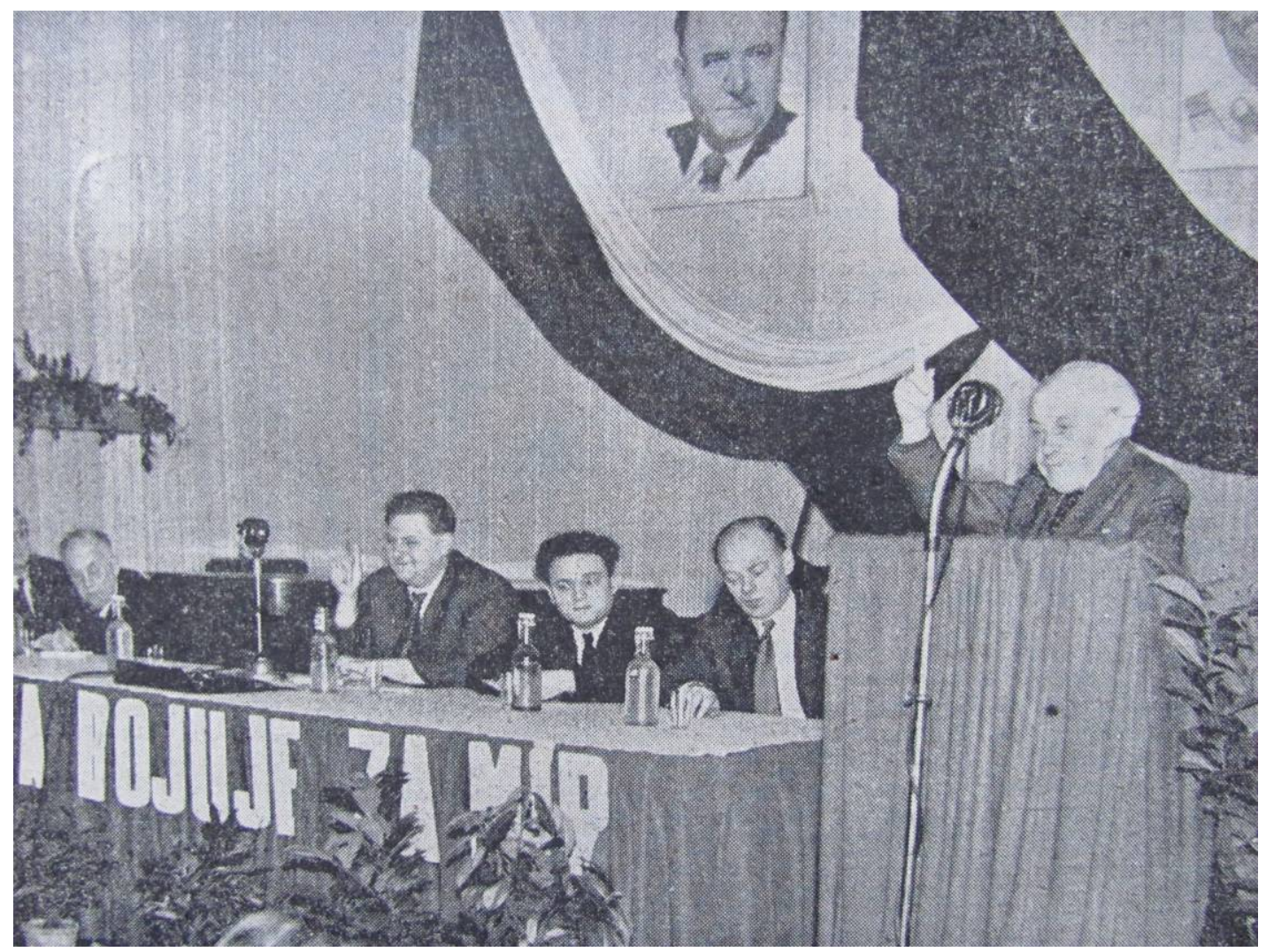

Figure 4. Zdeněk Nejedlý at the podium one year later at the UCC's second plenary conference in 1951.

The following pages are replete with phrases demonstrating the new Czechoslovak-Soviet solidarity. Barvík insists that "we fully agree with Khrennikov"128 regarding the contributions of Slavic nations to European civilization and "with Stalin we believe" in the blossoming of national cultures in the new socialist epoch. ${ }^{129}$ It was Stalin, in fact, who once said that the artist is to be "an engineer of the human spirit," an idea that flies flat in the face of the Kantian tradition of German idealism that had attempted to eradicate all political engagement from the arts through its objectivity. ${ }^{130}$ The new state fully embraces Stalin's motto and realizes that it is the government's responsibility to support artists in their endeavor to foster the socialist spirit. ${ }^{131}$ It is for this reason that the union shall offer grants for workshops, where musicians will be able to discuss, criticize, and help one another "reveal the path." ${ }^{132}$ In addition, monetary awards will be given to ensure composers' financial security. ${ }^{133} \mathrm{He}$ exclaims, "what other government, apart from ours, a people's democratic government, could allow for such events, could provide such convincing evidence for the generous support of artistic activity? Did the bourgeoisie care for art and artists in this way?"134 It then comes somewhat by surprise that Barvík announces the financial support that

\footnotetext{
${ }^{128}$ Tikhon Khrennikov (1913-2007), Barvík's Soviet counterpart as Secretary-General of the Union of Soviet Composers, was in attendance at the UCC's 1950 conference. See FIGURE 2.

${ }^{129}$ Ibid., 59-61.

${ }^{130}$ Ibid., 60.

${ }^{131}$ Ibid., 61.

${ }^{132}$ Ibid., 61.

${ }^{133}$ Ibid., 61.

${ }^{134}$ Ibid., 61.
} 
will be given to two casualties of his address who have apparently been given a second chance: the union will pay Karl Reiner eight months' salary so he is completely free to compose an opera, and a portion of Alois Hába's salary at the conservatory will be subsidized so he may realize what he has committed to by manifest, i.e., the production of new songs, choruses, cantatas, etc. ${ }^{135}$

Barvík returns to Stalin's motto through the words of Zhdanov, who had clarified what it really means to be an engineer of the human spirit. ${ }^{136}$ It means coming to an end with the older kind of romanticism, where the reader escapes from the oppression and conflict of the real world through the depiction of heroes in illusory situations. ${ }^{137}$ The new romanticism is revolutionary in nature and stands firmly on a materialistic foundation. ${ }^{138}$ Revolutionary romanticism must become the basic method of socialist realism, "for the strength of the country, the working class, and the proletarian struggle is contingent upon the fusion of the most rigorous, sober, and practical work with heroism of the greatest kind." 139

This holds true for all of the arts. It was before the war that Vladimír Helfert had called for something similar in music_ “a new greatness, a new pathos, a new monumentality, a new heroic idea." 140 And this is exactly what Zdeněk Nejedlý had pointed out during his arduous battle against the reactionary forces of the bourgeoisie, whose fraudulence and treachery he fully revealed. ${ }^{141}$

The creative artist now stands in front of these ideals. No longer does he need to stand silent in modest amazement in the face of the flagrant excesses of chic bourgeois art, nor bow to the opinions of decadent aestheticians. ${ }^{142}$ Instead, artists have now been granted the freedom to fulfill the honorable task of devoting their entire creative efforts to the construction of the new society. ${ }^{143}$ Barvík parts with the assembly with the motto of President Comrade Klement Gottwald, "FROM WORDS TO DEEDS!" and concludes:

We are led by our love for our native country and the working people, we are led by the example of the Soviet Union, we are led by our president Klement Gottwald and his great teacher, the teacher of nations, STALIN! $!^{144}$

\section{The Hatchet-Man Confesses}

Miroslav Barvík’s speech from April 1950 represents the official rhetoric on music during the "Sharp Course," the frenzied formative period of the Czechoslovak communist state. ${ }^{145}$ Lasting from Fall 1948 until Fall 1951, the Sharp Course was dominated by the Party's effort to restructure all areas of cultural life according to Soviet models and ideas. The UCC was one of several newly consolidated institutions that served as the gears for enforcing change. As a result of official policy, the arts were transformed into propaganda for the regime, a manipulator of public opinion, and a disseminator of

\footnotetext{
${ }^{135}$ Ibid., 62.

${ }^{136}$ Ibid., 63. Here Barvík derived his remarks from Zhdanov's 1934 speech to the Union of Soviet Writers, as published in Ždanov, 15-18.

${ }^{137}$ Barvík, Skladatelé, 63.

${ }^{138}$ Ibid., 63.

${ }^{139}$ Ibid., 63.

${ }^{140}$ Ibid., 63-4.

${ }^{141}$ Ibid., 64.

${ }^{142}$ Ibid., 64.

${ }^{143}$ Ibid., 64.

${ }^{144}$ Ibid., 64.

${ }^{145}$ See Knapík, V zajetí, 96 ff.
} 
ideologically defined culture. The contemptuous and disrespectful attitude of young apparatchiks such as Barvík towards older and eminent figures was justified by Stalin's thesis regarding the "intensification of the class struggle," which placed into the firing line any individual who could be suspected or "proved" of disloyalty to Party ideas.

In March 1951, the UCC held its second plenary conference, this time entitled "Our Music Fights for Peace," where Barvík once again gave the most extensive address. ${ }^{146}$ Maintaining the Sharp Course and the Korean War now serving as the backdrop, Barvík exhorts composers to contribute to peace in the world by highlighting the utopian conditions at home. Barvík's thesis holds that once the beauty of the nation is illuminated in full next to the "capitalist agitators" across the Atlantic, the virtues of the socialist path will be seen with complete clarity. Perhaps one of his most eccentric statements in this speech includes, "Each one of us can imagine the happy, singing, dancing Soviet person, but only with difficulty can we imagine a singing capitalist, or a dancing Churchill!" 147 One can imagine the mixed feelings of union members-obliged to attend these meetings on professional grounds-when listening to such absurd remarks. Indeed, the Party had continued to show its resolve through a string of political show trials, perhaps the most tragic of which concluded with the execution of the female politician Milada Horáková in July 1950.

The period from Fall 1951 to Fall 1952 represented a thaw in cultural politics. Heralding the thaw and sending shock waves throughout the political establishment was the imprisonment in November 1951 of Rudolf Slánský, the Secretary-General of the Communist Party. As Secretary-General, Slánský was the leader of the Party's Central Committee and its powerful Apparatus. It was the Party Apparatus, in fact, that had orchestrated support throughout society—or the illusion of public support-for the communist seizure of power. But since that time, the Apparatus had come under the suspicion of Gottwald and the government for having become a kind of competing, if not quasi-independent ministry. Although the secret orders for Slánskýs imprisonment had come directly from Stalin, the publicized accusations included attempting to create a "second center of power," fostering ties with "breakaway" Yugoslavia, and Zionism. The fact that Slánský was Jewish fell into the lap of his prosecutors, as American support of Israel had led the Soviet Union and its satellites to adopt the "battle against Zionism" as an additional feature of the official rhetoric. ${ }^{148}$

Toning down the vulgar radicalism of the Party Apparatus, the unions, and other organizations was part of the reasoning behind the Slánský affair. Sending a clear message to emboldened functionaries that power was being retracted to an elite circle around Gottwald was another motivation. Becoming the codeword of the day for reforming policy and purging the ranks was "slánština," or "Slánskýism," which became suddenly bandied about by functionaries as an excuse for excesses in power. The disarray in cultural life can be seen by the fact that many of the artistic union meetings scheduled for 1952, including the one of the UCC, were canceled. Slánský's imprisonment, which culminated in his trial and execution one year later, initiated a period when the unions were no longer certain whether they were accountable to

\footnotetext{
146“'Úkoly čs. skladatelů v boji za mír. Referát generálního tajemníka Svazu československých skladatelů Miroslava Barvíka, pronesený na slavnostním zasedání ÚV SČS dne 4. února 1951" ["Tasks for Czechoslovak Composers in the Battle for Peace: a Paper Read by the Secretary-General of the Union of Czechoslovak Composers Miroslav Barvík at the Ceremonial Session of the UCC's Central Committee on 4 February 1951"] Hudební rozhledy 3, nos. 10-12 (5 Jun. 1951): 4-13.

${ }^{147}$ Ibid., 9.

${ }^{148}$ For more on Slánský, see Karel Kaplan; Pavel Kosatík, Gottwaldovi muži [Gottwald's Men] (Prague: Paseka, 2004), 78-121 and Igor Lukeš, “The Rudolf Slansky Affair: New Evidence” Slavic Review 58, no 1. (Spring, 1999): 160-187.
} 
the Party Apparatus or the ministries, particularly the Ministry of Information, led by the government's most powerful ideologue Václav Kopecký. ${ }^{149}$

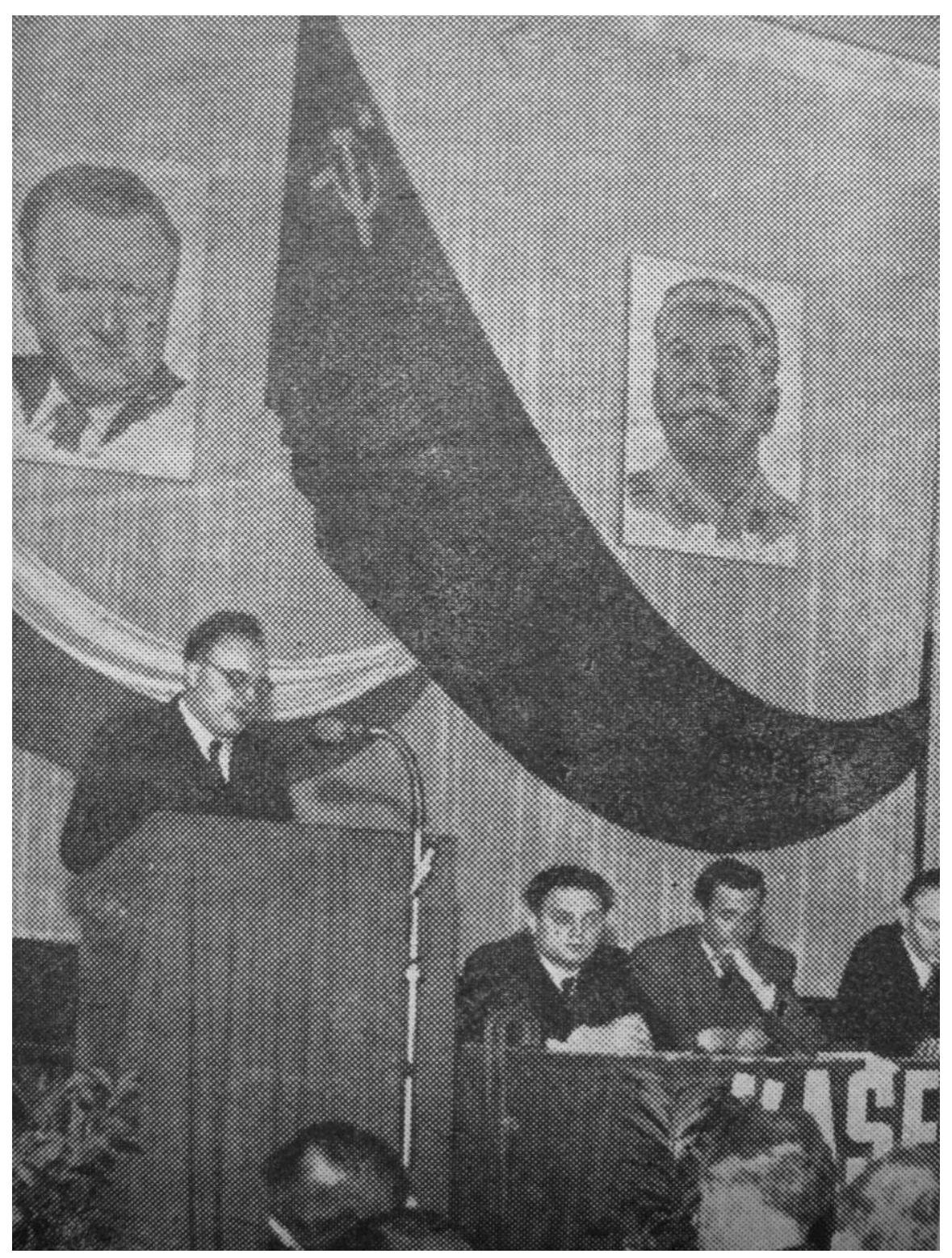

Figure 5. Miroslav Barvík delivering the concluding speech at the UCC's second plenary session in 1951. Seated in the panel are Jan Kapr, Dalibor Vačkár̆, and Jan Seidl.

\footnotetext{
${ }^{149}$ See Knapík, V zajetí, 322 ff. Along with 13 co-defendents (11 of whom were Jewish), Slánský was put on trial in an eight-day public spectacle that began on 20 November 1952. He was hanged in Pankrác Prison on 3 December 1952. The ironic fate of Slánský, one of the primary architects of labor camp repression, lies in the fact that he was convicted for crimes he had not committed, rather than those he had. See Kaplan; Kosatík, Gottwaldovi muži, 120.
} 


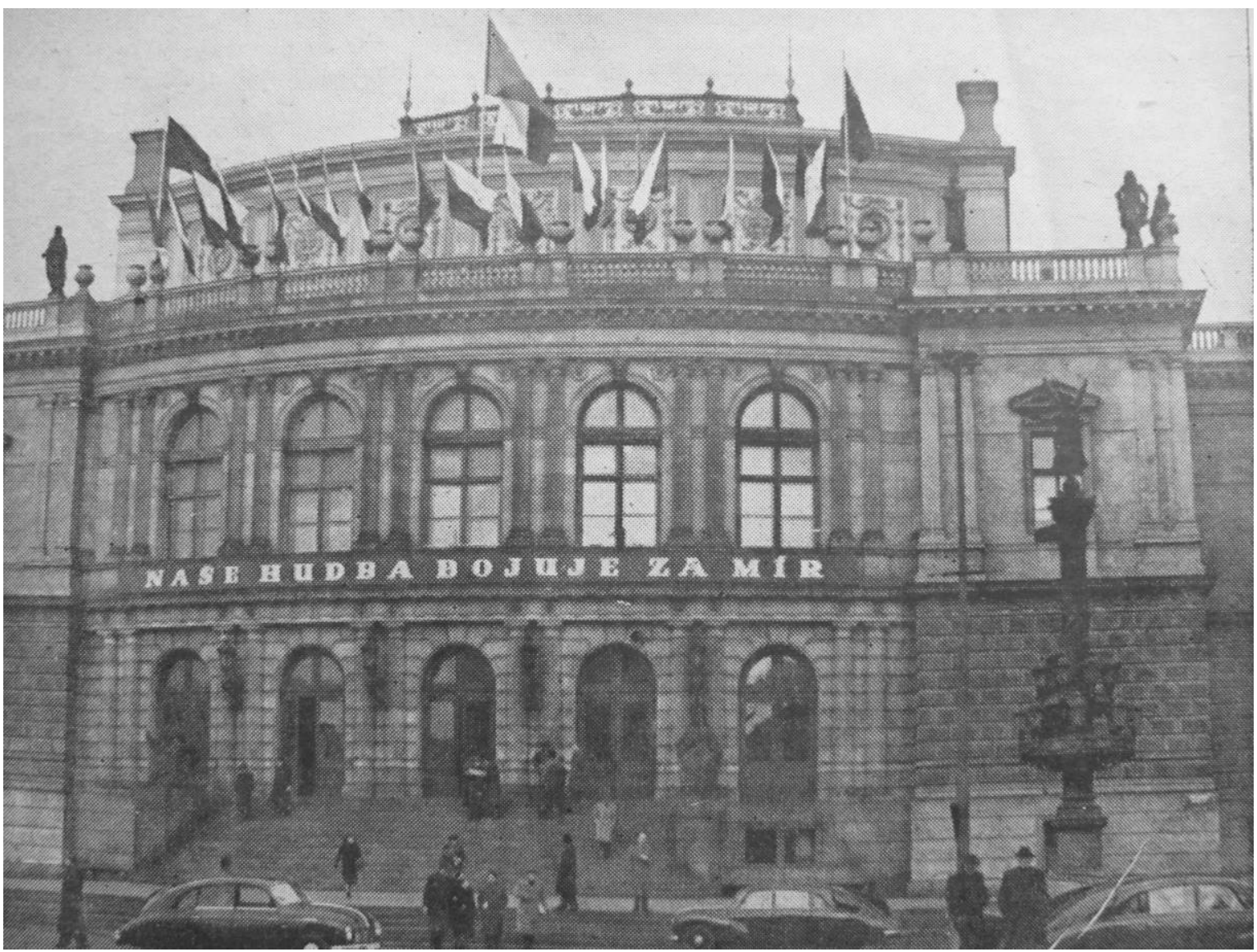

Figure 6: The House of Artists, today's Rudolfinum, adorned with the motto of the UCC's second plenary conference "Our Music Fights for Peace"

The Slánský affair made its definitive impact on musical life in February 1953, when the UCC's Central Committee held two critical meetings, the first of which was to honor Zdeněk Nejedlý upon the Education Minister's seventy-fifth birthday and rally support for the statewide conference that was to be held in June later that year. ${ }^{150}$ The real agenda of the meetings, however, was to initiate change in personnel and policy. For this reason, the union put forth as its motto "Criticism and Self-Criticism as a Powerful Weapon in the Battle for the New Music." ${ }^{151}$ The working mode of the meetings was to allow union executives to present self-criticism in a public forum, the typical duck-and-cover maneuver that was offered by functionaries when change was in the air. Opening the first meeting on 6-7 February was the UCC's Acting Chair Václav Dobiáš, who, without naming names, voiced concern about the elite circle running the union, who had become "a thorn in the eye to many." ${ }^{152}$ Commenting on the disrespect that had been done to older union members, he remarks that now, the younger members "have realized that the older comrades have their own particular values and that it would be a shame to let these values fall aside." 153 He also states that the union leadership had been working in isolation and that there were few

\footnotetext{
${ }^{150}$ See "Směleji a rozhodněji za rozvoj české a slovenské hudby" ["More Audaciously and Decisively for the Growth of Czech and Slovak Music"] Hudebni rozhledy 6, no. 9 (Jun. 1953): 372-383. The planned state-wide conference did not take place until 1955. See Knapík, V zajetí, 328.

151 "Směleji," 372.

${ }^{152}$ Ibid., 372.

${ }^{153}$ Ibid., 372.
} 
members willing to participate in executive management. ${ }^{154}$ In effect, Dobiáš was openly acknowledging that composers were not going with the union and that new people were needed at the helm.

Three weeks later, on 27-28 February, the UCC's Central Committee held the follow-up meeting that was to serve as the stage for Barvík's self-criticism. ${ }^{155}$ With the transcript to Dobiášs speech disseminated to union functionaries, Barvík gave his rambling, half-hearted confession. In numerous places and without further explanation, Barvík states that he agrees with Dobiášs speech, which he admits had been primarily about him. ${ }^{156}$ In a string of turgid formulations, he explains how "Slánskýism" had infected the UCC's working methods. ${ }^{157}$ After explaining how he "fell into" the position of SecretaryGeneral, from which he became accountable for so many facets of musical life, he describes how he had gradually assumed a feeling of "ineradicability, indispensability, inviolability, and infallibility." 158 Barvík clearly knew he was stepping down when he suggests that "it is necessary to insure future leadership that divides up the work and stays in touch with the people." 159 And after reminiscing about his role in the construction of post-Februarian musical culture, he admits what probably captured feelings about him the most:

I could talk about many things concretely. But if I were to summarize matters, I would say that, already in 1948, and perhaps even before that time, I earned a certain reputation-the reputation of the "hatchet-man." 160

By the end of 1953, the position of UCC Secretary-General was abolished, strengthening the position of the chairman and board, ${ }^{161}$ while the position of Editor-and-Chief at Hudebni rozhledy went to Jaroslav Jiránek. Barvík went on to become the Chair of the Music Division at the Ministry of Culture, remaining a reliable but less empowered ideologue in the Zhdanovite cultural front. ${ }^{162}$ The overall decentralization that went into gear at this time insured that no single functionary would ever have so much control over musical life. ${ }^{163}$ Contributing to the decline in the Zhdanovites' stranglehold over music was the currency reform measure of 1 June 1953, which ended the lavish flow of money from the Authors' Rights Protection Union for the production and performance of socialist works. Before this time, composers were generously supported to write "the new music" for concerts that went free of charge. But now, concert institutions had to fend for themselves: in the need to draw larger audiences, the priorities of programming went to the classics and international twentieth-century repertoire. And despite persistent

\footnotetext{
${ }^{154}$ Ibid., 373.

${ }^{155}$ Ibid., 375-377.

${ }^{156}$ Ibid., 375.

${ }^{157}$ As examples of Slánskýism, Barvík cites "the vulgarization and perversion of Marxist-Leninist theories through ostensibly revolutionary leftist demands that were hastily implemented with no regard to the current situation; the mechanization of MarxistLeninist, socialist-realist aesthetic principles; becoming alienated from the real life and feelings of man, sometimes under the garb of phrases about progress, socialism, etc.; the academic abstraction of impassioned artistic questions into incomprehensible analyses with no regard to real artistic work and the working methods of man today; 'building socialism' with only numbers, units, and statistics; a complete underestimation of man and his work; an inhumane, dryly calculated, coldly logical theorization of matters in relation to man; dictatorial interventions; the termination of independent organs; hectoring; etc." Ibid., 375.

${ }^{158}$ Ibid., 376.

${ }^{159}$ Ibid., 377.

${ }^{160}$ Ibid., 376. After his self-confession, members of the UCC Central Committee were given the opportunity to openly respond to Barvík's remarks. Vojtěch in particular did not let him off the hook so easily, grilling the lame-duck Secretary-General. See ibid., 380-81.

${ }^{161}$ Knapík, V zajetí, 327-328. As a note to clarify the union's structure, the chairman and board of the UCC's Central Committee met on a regular basis, i.e., in between meetings involving the UCC's entire Central Committee or the UCC as a whole. No longer needing to coordinate affairs with the General-Secretary, the UCC's chairman became the most important figure in the union.

${ }^{162}$ Ibid., 328.

${ }^{163}$ On the decentralization of musical life, see ibid., $273 \mathrm{ff}$.
} 
ideological interventions, the new situation allowed for certain artists, such as the Czech Philharmonic's Music Director Karel Ančerl, to become emboldened enough to refuse programming the socialist music generally viewed as inferior in artistic merit. ${ }^{164}$

Despite the appointment to Hudebni rozhledy of Jaroslav Jiránek-the most demonic of musical ideologues remembered for his Bolshevization of cultural programming at Czechoslovak Radio—a change in face for the official journal set in. ${ }^{165}$ Articles of a completely non-ideological nature began to share the rubrics with the socialist-realist items, gradually superseding them. A defining moment came in the 1954 edition dedicated to the fiftieth anniversary of Dvořák's death, where a heart-warming letter by Bohuslav Martinů was printed. ${ }^{166}$ Martinů, who apologized for being unable to travel in from abroad for the commemorations, enclosed a flower to be placed at Dvořák's grave. Martinůs gesture thoroughly moved the union's membership and underscored the difference in demeanor between the composer hitherto charged as a "traitorous émigré" and the fundamentalist policies of the union executives. ${ }^{167}$

The further attrition in ideological influence over the course of the 1950s led to the more genuinely liberal situation of the 1960s. Milestones in this process included the reestablishment of ties in 1955 between the UCC and the ISCM, which had been terminated since 1950; ${ }^{168}$ Khrushchev's 1956 speech denouncing Stalin and the cult of personality; the 1958 rehabilitation of Soviet Composers, which was printed in Hudebni rozhledy; ${ }^{169}$ and the death in 1961 of Václav Kopecký, who, by this time, had been completely abandoned by the eminent artists he had enjoyed surrounding himself with during his earlier years in office. ${ }^{170}$

\footnotetext{
${ }^{164}$ Thomas D. Svatos, Interview with Ivan Medek (Prague, Summer, 2007). At the time of the February 1948 coup, Ivan Medek (b. 1925) worked as Director of the Czech Chamber Orchestra. He remembers being called in by Barvík, who, in the capacity of Secretary to the Central Action Committee's Music Division, informed him that - by order of the Education Minister Zdeněk Nejedlý - Václav Talich was to be immediately dismissed as the ensemble's conductor. In disfavor throughout the course of the regime, Medek was a signatory of the Charter 77 proclamation on human rights, which ended his work with Supraphon Records. After interrogations by the state security apparatus, he immigrated to Austria in 1978. Settling in Vienna, he worked for Voice of America and Radio Free Europe until the 1989 Velvet Revolution. After 1989, he became an advisor to the Czech Philharmonic Orchestra and during 1993-1998 he worked in the office of the President Václav Havel, later becoming Chief of Staff.

${ }^{165}$ On Jiránek, see Knapík, Kdo byl kdo, "Jaroslav Jiránek," 120. Vojtěch described Jiránek's radicalism as a kind of "extremely radicalized trauma." He explained that Jiránek's father had been a police official during the First Republic, something Jiránek had considered a kind of genetic sin. Further commenting on the frightening figure, Vojtěch described the way Jiránek "could look through your eyes with a stone-faced look" and his demonic laughter. Svatos, Interview with Ivan Vojtěch. Before his death in 2001, I was fortunate to have met Jiránek and speak with him a number of times.

${ }^{166}$ See “Antonín Dvořák” Hudební rozhledy 7, no. 7 (1954): 263-267.

${ }^{167}$ See Svatos, Interview with Ivan Vojtěch. Martinů became a naturalized U.S. citizen in 1952, which prohibited him from traveling to the Soviet Block countries, including his home country of Czechoslovakia.

${ }^{168}$ See Knapík, V zajetí, 328.

${ }^{169}$ See "Usnesení Ústředního výboru Komunistické strany Sovětského svazu o nápravě chyb při hodnocení oper 'Velké přátelství,' 'Bohdan Chmelnickij' a 'Z celého Srdce"' ["Resolution of the Central Committee of the Communist Party of the Soviet Union on the Correction of Errors in the Appraisal of the Operas 'The Great Friendship,' 'Bohdan Khmelnitsky,' and 'With All One's Heart'”] Hudebni rozhledy 11, no. 12 (1958): 489.

${ }^{170}$ For more on Kopecký, see Kaplan; Kosatík, Gottwaldovi muži, 216-245.
} 


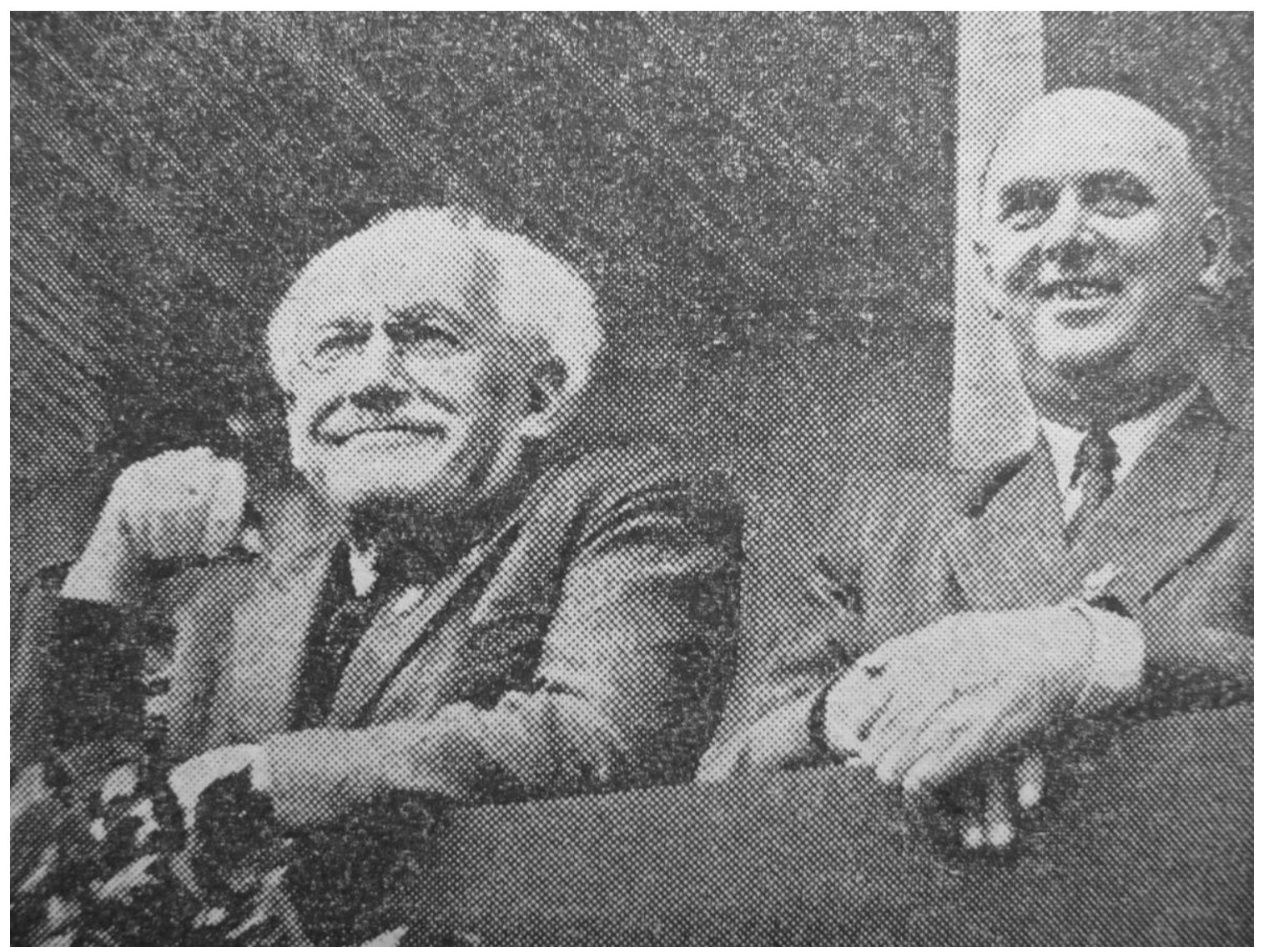

Figure 7. Ministers Zdeněk Nejedlý and Václav Kopecký watching the May-day parade from the platform, ca. 1948-53.

\section{Assessing Barvík and Communist Ideology}

Miroslav Barvík was one of several young careerists who fell to the intoxication of the postFebruarian atmosphere. From his speech The Composers Go with the People, there can be little question he believed an historic moment had arrived, which vindicated ruthless action, or justified turning a blind eye to the injustices being committed around him. Thus, how are we to appraise him today? And is it necessary to revise, or polemicize with the formulations he and other communist ideologues made in the service of the regime?

Before turning to these issues, we should note a bizarre twist in his story. As mentioned earlier, Barvík's earlier career is not widely remembered in today's Czech Republic. And in general, the subject of this study comes from a period many prefer to forget. But what further obscures Barvík's earlier work are the results of his later activities. In 1966, Barvík left his high-ranking positions in Prague's cultural life to become director of the Brno State Opera (now the Janáček Theater), a relocation that coincided with the gradual liberalization of cultural and political life, or what would later be called "socialism with a human face." Following the Soviet-led invasion in August 1968, Barvík joined the mass indignation, making a diametrical reversal from his earlier stance as a pro-Soviet cultural agent: he sanctioned the installation of a clandestine radio transmitter within the theater's premises to broadcast anti-Soviet relations. After the transmitter was discovered during the early phases of "Normalization," or the return to hard-line 
communist policy, Barvík was dismissed from the party, ending his career in cultural politics permanently. Today, in fact, Barvík is remembered not so much as a fundamentalist ideologue from the earlier years of communist dictatorship, but for his work as a radio presenter, as his popularizing classical music programs were a common fixture in homes across the country during the dying years of the socialist state. ${ }^{171}$

We should also note that, later in life, Barvík clearly regretted his work as an apparatchik. During his last year, Barvík wrote an autobiographical sketch in which he makes absolutely no reference to his role in the Action Committees, his editorship of Hudebni rozhledy, or his tenure with the UCC, choosing instead to focus on his scholarly work on Janáček, ${ }^{172}$ his directorship of the Brno State Opera (1966-72), his broadcasting activities on Czechoslovak Radio, and his lifelong activities as a theory and composition teacher. ${ }^{173}$ And showing that he never came to terms with his earlier work in communist cultural politics, Barvík - to our astonishment-even protests the injustices he had suffered during the Normalization, particularly the censorship of his work. ${ }^{174}$ Indeed, crying out injustice at the hands of the new cadre of communists who came to power during the Soviet occupation provides an historical irony, as it was Barvík himself who took a leading role in the construction and canonization of the structures that later hindered his own artistic ambitions.

The focus of this study will undoubtedly draw protest in certain circles in today's Czech Republic as a subject that should remain buried rather than revisited. The fact that the communist period is still relatively fresh and affects the immediate descendents of those who were persecuted or participated might even deem my study reprehensible. My view, however, is that in a national culture where the past has been forcibly revised and erased so many times (i.e. 1918, 1938-9, 1948, 1968-9, and 1989), historical enquiries providing full disclosure of events and its principal actors are greatly needed.

But when we hold accountable the collaborators of the regime, we might ask ourselves how we might have acted as leftist-minded intellectuals in the post-World War II climate, when visions of a more just society seemed so near at hand. ${ }^{175}$ We might ask ourselves—had we come to maturity during the Nazi occupation and Soviet liberation-would we have been able to clearly identify the dangers of the Soviet Union? Or would we have stepped back once, by late 1948, there could be no question about the violent tactics of the communist regime? In the case of Miroslav Barvík-for whom political idealism and the allures of careerism were all too strong-we have an individual who did not take a back-seat role, becoming instead one of the most dangerous participants of a most dangerous regime.

In my coverage of The Composers Go with the People, I have made available to English-language readers the story of Czech music according to the communists. But I have made no attempt at correcting Barvík's innumerable lies, distortions, and euphemistic manipulations. ${ }^{176}$ Undoubtedly providing no comfort to musicians who were hurt during this period is my view that polemics with the determinism of

\footnotetext{
${ }^{171}$ Svatos, Interview with Ivan Vojtěch.

${ }^{172}$ In the field of Janáček studies, Barvík is not known for any vital contributions.

${ }^{173}$ See Miroslav Barvík, “Autobiografie” [“Autobiography”] Miroslav Barvik Memorial Website: http://web.iol.cz/mbk/ (Accessed Nov., 2007). The website, now removed from the internet, included a number of obituaries that weighed in on Barvík's career positively and negatively; I was fortunate to have secured all of the texts from the site before it was discontinued.

${ }^{174}$ Ibid.

${ }^{175}$ For more on this line of thought, see Jůzl, $38 \mathrm{ff}$.

${ }^{176}$ For studies on the manipulative nature of Czech communist musicology, see Vladimír Karbusický, "K technologii pamfletů o hudbě z let 1948-1952" ["Towards the Technology of Pamphlets about Music during the Years 1948-1952"] Hudební věda 6, no. 2 (1969): 281-311 and Monika Kroupová, “Totalitní jazyk a jeho úloha v českém hudebním časopisectví na přelomu 40. a 50. let 20. století" ["Totalitarian Language and its Role in Czech Music Journalism at the Turn of the 1940s and 1950s"] Opus musicum 34, no. 1 (2002): 13-17.
} 
communist ideology bear few rewards. Another shortcoming might be found in the fact that I have provided no account of how musicians dealt with the harsh circumstances and carried on with their work.

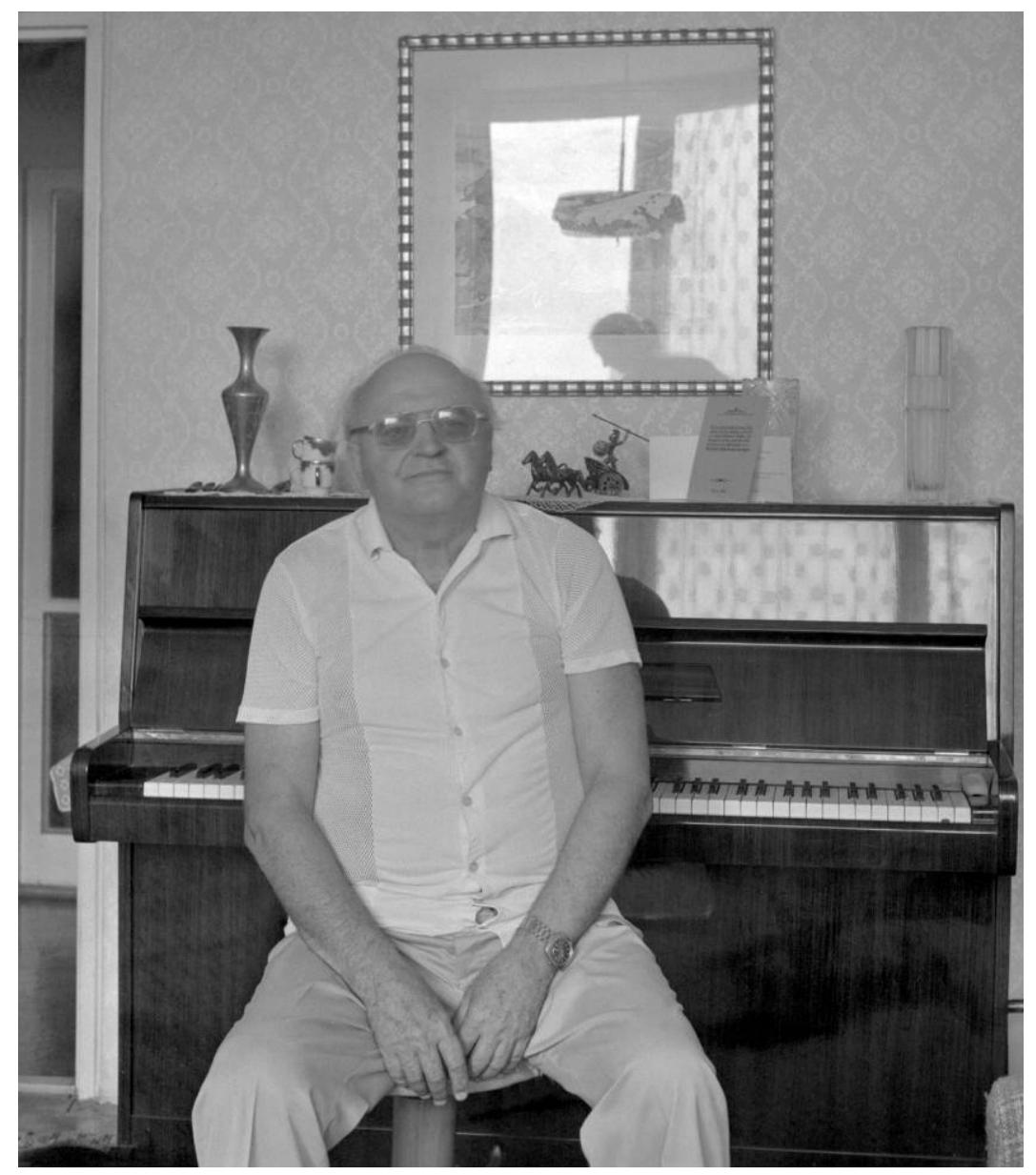

Figure 8. Miroslav Barvík in his later years.

But to shed at least some contrasting light on the official record, I shall provide a hitherto undocumented anecdote about Alois Hába, a musician disenfranchised by Barvík and the regime. In his 1950 speech, Barvík frames the UCC's “subsidation” of Hába's salary at the conservatory-which was "to free him" so he could compose socialist music_as a benevolent act of the state. But in reality, Barvík's formulation was a cover for the embarrassing fact that Hába, a composer of international repute, was about to be dismissed from HAMU, the newly established music academy, where Hába's department for microtonal composition had already been discontinued. ${ }^{177}$ Well-known for his indestructible personality,

\footnotetext{
${ }^{177}$ For more on Hába's career during this period, see Jiř́ Vysloužil, Alois Hába. Život a dílo [Alois Hába. Life and Works] (Prague: Panton, 1974), 277-296. From Vysloužil's monograph, I am led to believe that, although Barvík stated that Hába's salary was to be subsidized at the conservatory, he was actually referring to Hába's other position at HAMU. My conclusion comes from the fact that Hába signed "his" contract to compose socialist music with HAMU's Rector's Office. The contract is dated 1 February 1950 and the conference The Composers Go with the People took place not long thereafter on 22-25 April 1950; Barvík probably conceived his speech during the time in between. The confusion may come from the fact that, at this time, the Prague Conservatory and HAMU were still viewed in some sense as the same institution, as HAMU had been established only a few years earlier in 1945 on the basis of the Prague Conservatory's Master Class, where Hába had been part of the leading faculty. At HAMU, Hába's division for microtonal music was abolished at the beginning of the 1948-9 academic year and his contract there was discontinued upon the 19501 academic year, or the next academic year after Barvík's speech. Through a decision of the Ministry of Education on 12 July 1951 ,
} 
Hába made an open mockery of the young ideologues at the UCC's 1951 plenary conference by forcing one of the sessions to an abrupt close. At one moment, when a fair number of auditors were nodding off, Hába suddenly raised his voice from the back of the hall crying out, "And I would like to say something!" He then went up to the podium and placed a stack of manuscript paper on the table exclaiming, "I'm in favor of a productive discussion, but what you've been saying here are empty phrases. During the time you've been speaking I've composed 40 mass songs. Here they are." Caught by surprise, the speaker replied, "Thank you for your contribution, Comrade Hába, I think we can bring matters to a close now." 178

Thus what I have provided in this study is mostly a surface level transmission of a speech representing the official musical ideology in communist Czechoslovakia, which was enforced over forty years according to the political climate of the time. How we shall reconcile with the communist-era musicological literature will remain a dilemma for some time to come, as it was almost always subject to either official or auto-censorship. ${ }^{179}$ Indeed, the vast majority of communist-era writings pose great dangers to the undiscerning eye, with those colored more subtly by official policy, or carefully omitting disagreeable facts and opinions, more hazardous than the self-evident dogmatic tracts. And how these sources have been transmitted into the international literature complicates matters exponentially. Indeed, whether there will be the courage to redress the misinformation about Czech music that was created during the communist era, or whether a strategy will be found for interpreting the communist-era sources, remains a question only the future can answer. ${ }^{180}$

\footnotetext{
Hába's contract at the conservatory was almost terminated as well, had it not been for the intervention of the conservatory's director, Václav Holzknecht, who found a way to allow Hába to remain under contractual employment until his retirement in 1953 by creating a position for him in the conservatory library, through which Hába continued to meet with students.

${ }^{178}$ This anecdote was related to me in Svatos, Interview with Ivan Vojtěch. Vojtěch also notes that the funds for Hába's stipend came not from the UCC, as Barvík announced, but from the Authors' Rights Protection Union. There is no mention of Hába's stunt in the article in Hudebni rozhledy that reports on the 1951 conference. See Úkoly, 4-13.

${ }^{179}$ For more on the issue of censorship and auto-censorship, see Jůzl, $45 \mathrm{ff}$.

${ }^{180}$ For the positive role they played in the creation of this study, I would also like to thank Volker Ahmels, Jan Andreska, Jan Asmussen, Marcel Černý, Nicolas Deletaille, Brian Locke, Jan Kahuda, Jiří Knapík, Jiří Křest’an, Martin Sekera, Tomislav Volek, David Walters, and Anke Zimmermann. I would also like to pay my most sincere respect to Jan Kuklík (1940-2009), historian and specialist of the Protectorate of Bohemia and Moravia, who granted me invaluable consultations on the subject of modern Czech history during my research residences in Prague.
} 


\section{Bibliography}

Adorno, Theodor. "Die Gegängelte Musik.” Gesammelte Schriften 14: 51-66. Frankfurt am Main: Suhrkamp Verlag, 1973.

"Hudba na provázku” ["Music on a Leash”]. Hudební véda 6, no. 1 (1969): 92-101.

Barvík, Miroslav. "Autobiografie" ["Autobiography"]. Miroslav Barvík Memorial Website: http://web.iol.cz/mbk/ (Accessed Nov., 2007).

- Skladatelé jdou s lidem: referát generálnîho tajemníka Svazu čs. skladatelů na I. plenárním zasedání SČS $v$ dubnu 1950 [The Composers Go with the People: A Paper Read by the Secretary-General of the Union of Czechoslovak Composers at the First Plenary Meeting of the UCC in April 1950]. Prague: Orbis, 1951.

. Untitled Journal Mission Statement. Hudební rozhledy 1, no. 1 (15 Oct. 1948): 1-2.

Bek, Mikuláš. "Socialist Realism and Anti-Modernism in Czech Music." Socialist Realism and Music. Edited by Mikuláš Bek, Geoffrey Chew, and Petr Macek, 52-60. Prague: Koniasch Latin Press, 2004.

Blažek, Zdeněk. Dvojsměrná alterace v harmonickém myšlení. [Two-way Alteration in Harmonic Thought]. Brno: Rovnost, 1949.

Borio, Gianmario and Danuser, Herman. Im Zenit der Moderne: Die Internationalen Ferienkurse für neue Musik, Darmstadt 1946-66. 4 vols. Freiburg: Rombach Verlag, 1997.

Botstein, Leon. "Modernism." The New Grove Dictionary of Music and Musicians. 2nd ed., edited by John Tyrrell, 16: 868-875. London: Macmillan, 2001.

Bouček, Jaroslav. "Dva tábory v boji o francouzskou kulturu" ["Two Camps in the Battle over French Culture”]. Var 3, no. 2 (1 Apr. 1950): 42-53.

Bush, Alan. "The Second International Congress of Composers and Music Critics." The Musical Times (Sep., 1948): 280-81.

Chew, Geoffrey. "Václav Dobiášss Celebration of Proletarian Prague: The Song Cycle Praho jediná." Socialist Realism and Music. Edited by Mikuláš Bek, Geoffrey Chew, and Petr Macek, 214-223. Prague: Koniasch Latin Press, 2004.

Červinka, František. Zdeněk Nejedlý. Prague: Melantrich, 1969.

Černý, Miroslav. "Ke kritikám 'Pražského manifestu' od Adorna ke sborníku Musik und Politik” [“From Adorno's Criticisms of the 'Prague Manifesto' to the Essay Collection Musik und Politik"]. Hudební véda 10, nos. 3 \& 4 (1973): 234-243, 326-338.

Československý hudební slovník [Czechoslovak Music Dictionary]. Prague: Státní hudební vydavatelství, 1963.

Čeští skladatelé současnosti [Contemporary Czech Composers]. Edited by Alena Martínková. Prague: Panton, 1985.

Dobiáš, Václav. Buduj vlast - posílís mír!, Československá polka [Build Up Your Country to Reinforce Peace! A Czechoslovak Polka]. Prague: Orbis, 1950. 
Tři poetické polky pro klavír [Three Poetic Polkas for Piano]. Prague: Orbis, 1950.

Duchacek, Ivo. “The February Coup in Czechoslovakia.” World Politics 2, no. 4 (Jul., 1950): 511-532.

. "The Strategy of Communist Infiltration: Czechoslovakia, 1944-48." World Politics 2, no. 3. (Apr., 1950): 345-372.

Havlík, Jaromir. "The Prague Manifesto after (almost) sixty years." (1 Apr. 2007). The Free Library, http://www.thefreelibrary.com.

Hostinský, Otakar. Studie a kritiky [Studies and Reviews]. Prague: Československý spisovatel, 1974.

Hudba národů. Sborník prednášek proslovených na I. mezinárodním sjezdu skladatelì a hudebních kritiků v Praze ve dnech 16.-26. V. 1947 [Music of the Nations: Proceedings of the First International Congress of Composers and Music Critics in Prague during the days 16-26 May 1947]. Prague: Syndikát českých skladatelů, 1948.

Jan Hus_Jan Žižka_Proti všem. Dir. Otakar Vávra. Prague: Studio uměleckých filmů, 1954, 1955; Filmové Studio Barrandov, 1957.

Janáček, Leoš. Hudebně teoretické dílo [Works in Music Theory]. 2 vols. Edited by Zdeněk Blažek. Prague: Editio Supraphon, 1968; 1974.

Janeček, Karel. Tema con variazioni, op. 23. Prague: Hudební matice Umělecké besedy, 1949.

Jůzl, Miloš. "Music and the Totalitarian Regime in Czechoslovakia." International Review of the Aesthetics and Sociology of Music 27, no. 1. (Jun., 1996): 31-51.

Kaplan, Karel; Kosatík, Pavel. Gottwaldovi muži [Gottwald’s Men]. Prague: Paseka, 2004.

Karbusický, Vladimír. "K technologii pamfletů o hudbě z let 1948-1952" ["Towards the Technology of Pamphlets about Music during the Years 1948-1952”]. Hudebni věda 6, no. 2 (1969): 281-311.

Knapík, Jiří. Kdo byl kdo v naši kulturní politice 1948-1953 [Who was Who in our Cultural Politics 1948-1953]. Prague: Nakladatelství Libri, 2002.

—. Únor a kultura. Sovětizace české kultury 1948-1950 [February and Culture: The Sovietization of Czech Culture 1948-1950]. Prague: Nakladatelství Libri, 2004.

—.V zajetí moci. Kulturni politika, jeji systém a aktéri 1948-1956 [In the Captivity of Power: Cultural Politics, its System, and Participants 1948-1956]. Prague: Nakladatelství Libri, 2006.

Kroupová, Monika. "Totalitní jazyk a jeho úloha v českém hudebním časopisectví na přelomu 40. a 50. let 20. století" ["Totalitarian Language and its Role in Czech Music Journalism at the Turn of the 1940s and 1950s"]. Opus musicum 34, no. 1 (2002): 13-17.

Křest’an, Jiří. “Poslední husita” odchází: Zdeněk Nejedlý v osidlech kulturní politiky KSČ po roce 1945” [“The Last Hussite' Departs: Zdeněk Nejedlý in the Snares CCP Cultural Politics after 1945”]. Soudobé dějiny 12, no. 1 (2005): 9-44. 
Kuna, Milan. Dvakrát zrozený. Život a dílo Karla Reinera [Twice Born. The Life and Works of Karl Reiner]. Prague: H + H, 2008.

Kundera, Ludvík. Václav Kaprál. Kapitola z historie české meziválečné hudby [Václav Kaprál: A Chapter from the History of Czech Interwar Music]. Brno: Nakladatelství Blok, 1968.

Leibowitz, René. L'Artiste et sa conscience, Esquise d'une dialectique de la conscience artistique. Préface de J.P. Sartre. Paris: L'Arche, 1950.

Locke, Brian S. Opera and Ideology in Prague: Polemics and Practice at the National Theater, 1900-1938. Rochester: University of Rochester Press, 2006.

Löwenbach, Jan. Hudba v Americe [Music in America]. Prague: Hudební matice Umělecké besedy, 1948.

Lukeš, Igor. “The Rudolf Slansky Affair: New Evidence.” Slavic Review 58, no. 1. (Spring, 1999): 160-187.

Macek, Petr. Smëleji a rozhodněji za českou hudbu!: "společenské védomí" české hudební kultury 1945-1969v zrcadle dobové hudebni publicistiky [More Audaciously and Decisively for Czech music! "The Social Conscious" of Czech Musical Culture during the Years 1945-1969 in the Mirror of Contemporary Music Criticism]. Prague: KLP-Koniasch Latin Press, 2006.

MacKay, John. “An Overview of Karel Janeček's Foundations of Modern Harmony” ex tempore 11, no. 1 (2002): 1-43.

Macura, Vladimír. Št’astný věk: Symboly, emblémy a mýty 1948-1989 [The Happy Period: Symbols, Emblems, and Myths 1948-1989]. Prague: Pražská imaginace, 1992.

Neumann, S.K. Anti-Gide, neboli optimismus bez pověr a ilusí [Anti-Gide, or Optimism without Superstitions and Illusions]. Prague: Vydavatelstvo Družstevní Práce, 1950.

Pantůček, Viktor. "Musica politica. Budování nového řádu” [“Musica Politica: Building the New Order”]. Opus musicum 39, no. 1 (2007): 36-37.

Paulová, Eva. "Obraz jako zbraň bojů o Dvořáka a Smetanu" ["The Picture as a Weapon in the Battles over Dvořák and Smetana”]. Opus musicum 34, no. 1 (2002): 21-26.

Peduzzi, Lubomír. Zdeněk Blažek. Obraz života a díla [Zdeněk Blažek: A Picture of his Life and Work]. Brno: Kulturní klub NV, 1988.

Pozner, Vladimír. Rozpojené státy [Divided States]. Prague: Nakladatelství Svoboda, 1949.

"Provolání" ["Proclamation" \{"Prague Manfesto"\}]. Hudební rozhledy 1, no. 1 (15 Oct. 1948): 40-41.

Reiner, Karel. Sonata No. 2 for Piano Solo. Prague: Melantrich, 1947.

Sehnal, Jiří and Vysloužil, Jiřri. Dějiny hudby na Moravě [A History of Music in Moravia]. Brno: Muzejní a vlastivědná společnost v Brně, 2001.

Sinn und Form, Sonderheft Hanns Eisler. Berlin, 1964. 
"Skladatelé jdou s lidem. Zpráva o I. pracovním plenárním zasedání Svazu čs. skladatelů ve dnech 22.-25. IV. 1950" ["Composers Go with the People: A Report on the First Working Plenary Session of the Union of Czechoslovak Composers during the Days 22-25 April 1950"]. Hudebni rozhledy 2, nos. 8-9 (25 June 1950): 198-233.

Slonimsky, Nicolas. Music Since 1900. 5th ed. New York: Schirmer Books, 1994.

"Směleji a rozhodněji za rozvoj české a slovenské hudby" ["More Audaciously and Decisively for the Growth of Czech and Slovak music”]. Hudebni rozhledy 6, no. 9 (Jun. 1953): 372-383.

Svatos, Thomas. "A Clash over Julietta: the Martinů/Nejedlý Political Conflict and Twentieth-Century Czech Critical Culture" ex tempore (2009).

—. Interview with Ivan Medek. Prague, Summer, 2007.

—. Interview with Ivan Vojtěch. Prague, Summer, 2006.

—. "Martinů on Music and Culture: a View from his Parisian Criticism and 1940s Notes." PhD diss., University of California, Santa Barbara, 2001.

—. "Reasserting the Centrality of Musical Craft: Martinů and his American Diaries" The Musical Times 2 (2009): 55-70.

Štilec, Jiř́. Václav Dobiáš. Prague: Panton, 1985.

Štoll, Ladislav. Třicet let bojů za českou socialistickou poesii [Thirty Years of Battles over Czech Socialist Poetry]. Prague: Orbis, 1950.

"Úkoly čs. skladatelů v boji za mír. Referát generálního tajemníka Svazu československých skladatelů Miroslava Barvíka, pronesený na slavnostním zasedání ÚV SČS dne 4. února 1951" ["Tasks for Czechoslovak Composers in the Battle for Peace: a Paper Read by the Secretary-General of the Union of Czechoslovak Composers Miroslav Barvík at the Ceremonial Session of the UCC's Central Committee on 4 February 1951”]. Hudebni rozhledy 3, no. 10-12 (5 Jun. 1951): 4-13.

"Usnesení Ústředního výboru Komunistické strany Sovětského svazu o nápravě chyb při hodnocení oper 'Velké přátelství', 'Bohdan Chmelnickij' a 'Z celého srdce'” ["Resolution of the Central Committee of the Communist Party of the Soviet Union on the Correction of Errors in the Appraisal of the Operas 'The Great Friendship,' 'Bohdan Khmelnitsky,' and 'With All One's Heart"”]. Hudebni rozhledy 11, no. 12 (1958): 489.

Vojtěch, Ivan. "Martinů a soudobá česká hudba" ["Martinů and Contemporary Czech Music"]. Literární noviny 7, no. 25 (21 Jun. 1958): 5.

Vysloužil, Jiří. Alois Hába. Život a dílo [Alois Hába: Life and Works]. Prague: Panton, 1974.

Waters, Julie. "Proselytizing the Prague Manifesto in Britain: The Commissioning, Conception, and Musical Language of Alan Bush's 'Nottingham' Symphony" Music and Politics 3, no. 1 (Winter 2009).

Werth, Alexander. Musical Uproar in Moscow. Westport, Conn.: Greenwood Press, 1973. 
"Zpráva o činnosti rehabilitační a rekapitulační komise sekce hudebních vědců a kritiků Svazu čs. skladatelü" ["Report on the Activities of the Rehabilitation and Recapitulatory Commission of the Section of Musicologists and Music Critics of the Union of Czechoslovak Composers"]. Hudebni véda 6, no. 2 (1969): 326-339.

Ždanov, Andrej A. O umění [About Art]. Prague: Orbis, 1949.

"II. sjezd československých skladatelů a hudebních vědců" ["Second Conference of Czechoslovak Composers and Musicologists"]. Hudebni rozhledy 1, no. 10 (20 Aug. 1949): 224-226.

\begin{abstract}
This article offers a close-up view of musical politics during the early and most repressive years of the Czechoslovak communist regime. Forming the focus is Miroslav Barvík (1919-1998), the top apparatchik in music at this time. Examined here are the political forces that gave Barvík the authority to create and control a highly centralized musical arena to implement Soviet ideas. Given extensive treatment is his 1950 speech to the Union of Czechoslovak Composers entitled The Composers Go with the People. What on the surface level was a call for musicians to join the socialist struggle was in reality an instruction for them to prove themselves ideologically. Barvík's speech reveals the story of Czech music according to the communists and shows which musicians were favored or disenfranchised. Barvík is virtually unknown internationally and even in today's Czech Republic, he is somewhat forgotten. Thus the article also considers the forces that led to his neutralization as the strong-man of the Czech music scene as well as the circumstances that account for his disappearance from the Czech historical conscience.
\end{abstract}

